\title{
Agriculture for Jobs and Growth in the Western Balkans
}
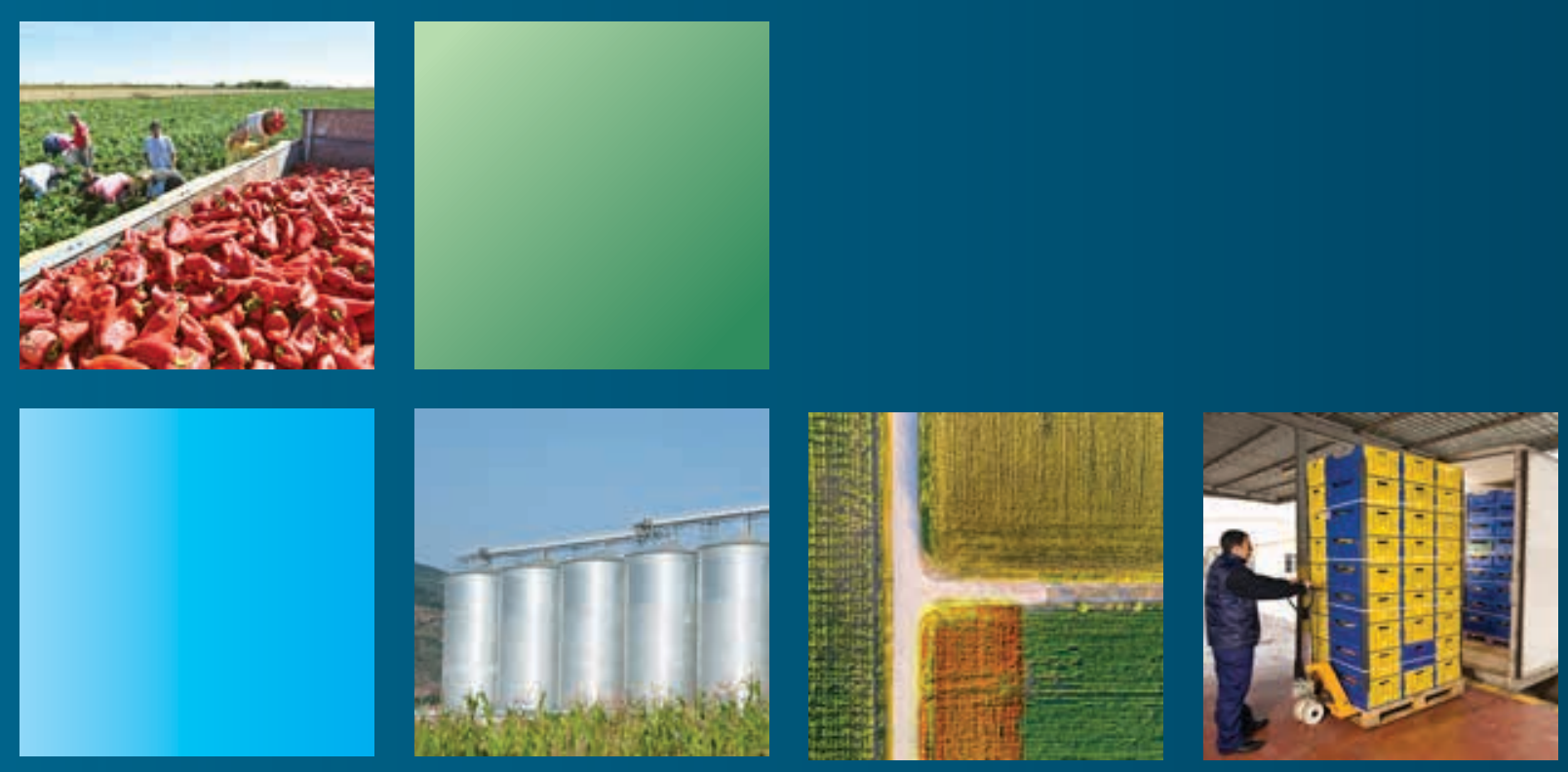

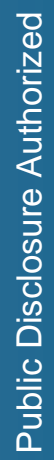
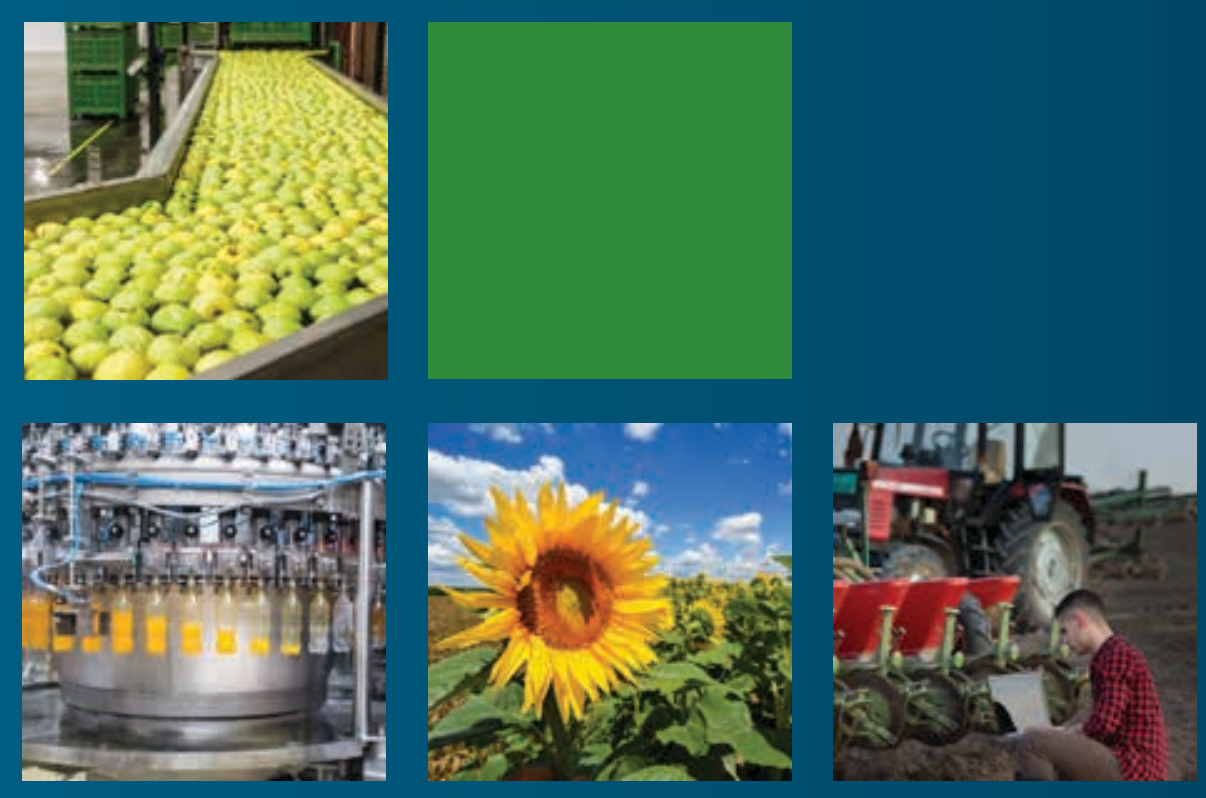

(4) WORLD BANK GROUP
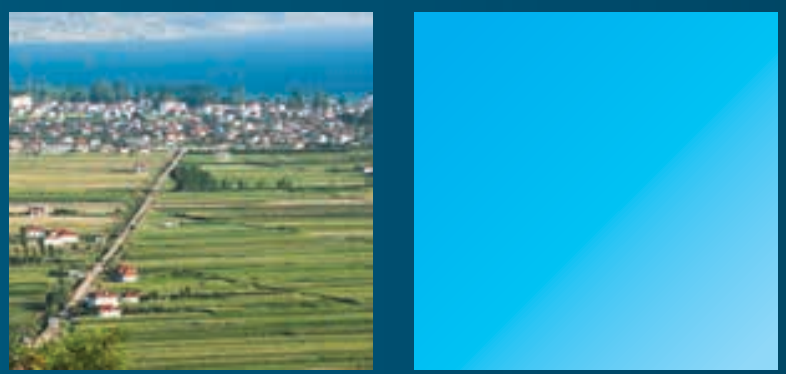



\title{
Agriculture for Jobs and Growth in the Western Balkans
}

\author{
A Regional Report
}

June 2017 


\section{Acronyms}

$\mathrm{BiH} \quad$ Bosnia and Herzegovina

CAP Common Agricultural Policy

CEFTA Central European Free Trade Area

CENELEC European Committee for Electrotechnical Standardization

EU European Union

FADN Farm Accountancy Data Network

FAO Food and Agriculture Organization

FDI Foreign Direct Investment

GDP Gross domestic product

Gls Geographical Indications

HACCP Hazard analysis and critical control points

IPARD Instrument for Pre-Accession Assistance for Rural Development

NSBs National Standards Bodies

SME Small and medium enterprise

SO Standard output

SPS Sanitary and phytosanitary

USD United States Dollars

VET Vocational Education and Training

WB Western Balkan (region, country) 


\section{Table of Contents}

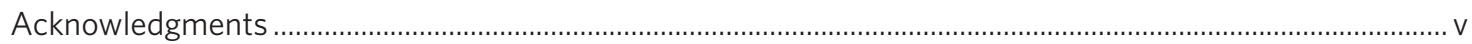

Executive Summary $\ldots \ldots \ldots \ldots \ldots \ldots \ldots \ldots \ldots \ldots \ldots \ldots \ldots \ldots \ldots \ldots \ldots \ldots \ldots \ldots \ldots \ldots \ldots \ldots \ldots \ldots \ldots \ldots \ldots \ldots \ldots \ldots \ldots \ldots \ldots \ldots \ldots \ldots \ldots \ldots \ldots \ldots \ldots \ldots \ldots \ldots \ldots$

I. Study Objectives and Scope ................................................................................................................. 4

II. Framework and Context................................................................................................ 6

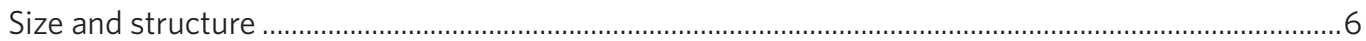

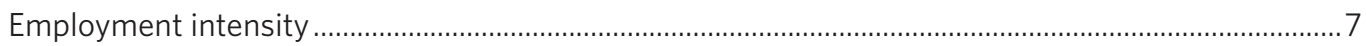

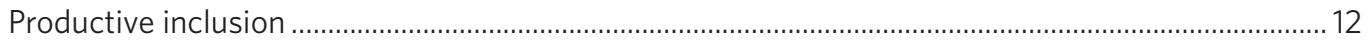

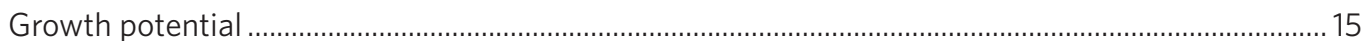

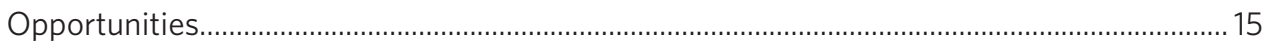

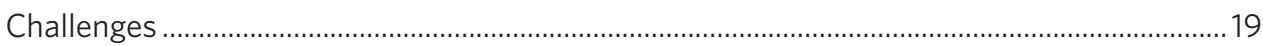

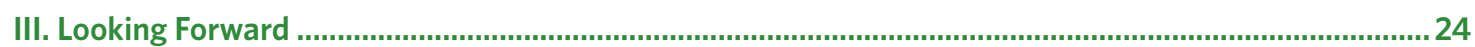

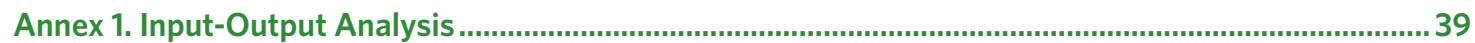

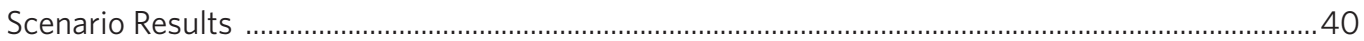




\section{List of Figures}

Figure 1. While most countries in the region are in a process of transitioning out of agricultural based economies, Albania continues to heavily depend on its rural economy

Figure 2. The share of food, beverage and tobacco manufacturing turnover of total manufacturing turnover is large in the

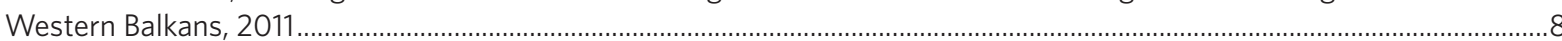

Figure 3.A. Concentration of food and beverage manufacturing in CEFTA ${ }^{\star}, 2008-10$............................................................................. 8

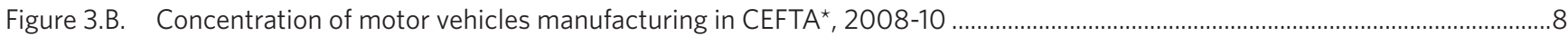

Figure 4. The share of food, beverage and tobacco manufacturing employment in total manufacturing employment is Important, $2011 \ldots . .9$

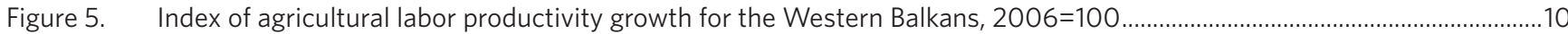

Figure 6. The average value added per employee in the food, beverage and tobacco manufacturing industry is very low, $2011 \ldots \ldots . . . .11$

Figure 7. The average wages and salaries in the food, beverage and tobacco manufacturing industry are very low, 2011.................. 12

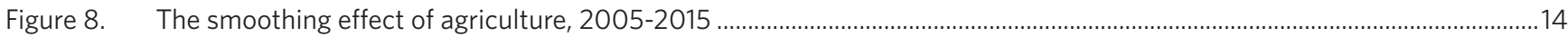

Figure 9. Exports of food and beverages from WB countries have grown faster than total world exports, 2006-2012 …...................17

Figure 10. Value addition in agri-food exports is significant, 2011.................................................................................................... 18

Figure 11. Trade deficits of processed food and beverages are large for $\mathrm{BiH}$, Albania and Montenegro, 2013 …....................................19

Figure 12.A. Food and beverages represent a large share of manufacturing turnover, 2009...................................................................20

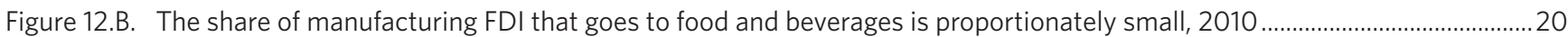

Figure 13. The food, beverage and tobacco manufacturing enterprises employ a large number of people, 2011................................. 22

Figure 14. The average turnover of food, beverage and tobacco manufacturing enterprises is small, 2011 ........................................... 23

Figure 15. The density of food, beverage and tobacco manufacturing enterprises (per million inhabitants) is similar to the EU, $2011 \ldots . . . . .23$

Figure 16. The average gross fixed capital formation of food, beverage and tobacco manufacturing enterprises is small, 2011 .......... 23



Figure 18. Share of agri-food sector employees by agri-food sub-system, 2012 …........................................................................... 37

\section{List of Tables}

Table 1. Macroeconomic indicators, Western Balkans, 2015

Table 2. Average size of agricultural holding (ha) and number of agricultural holdings .........................................................................13

Table 3. Share of holdings by size of farmed area in selected WB countries (\%) ..............................................................................14

Table 4: $\quad$ Share of (semi-) subsistence farmers in selected WB countries (\%) …….......................................................................... 15

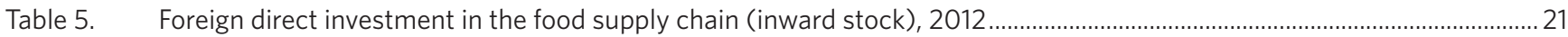

Table 6. Economic impacts of the agri-food sector in Albania and North Macedonia ........................................................................ 25

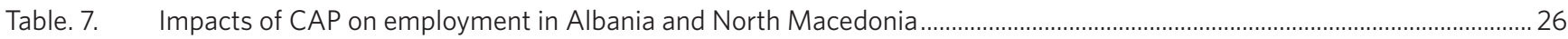

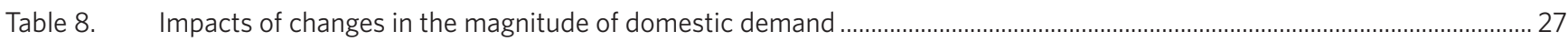

Table 9. Impacts of policy scenario compared to status quo (Ratio: scenario impacts/status quo impacts), Albania........................ 41

Table 10. Impacts of policy scenario compared to status quo (Ratio: scenario impacts/status quo impacts), North Macedonia..... 42

Table 11. Impacts of structural scenarios (changes compared to 2013) ….........................................................................................43

Table 12. Impacts of structural scenarios (compared to no change in policy, 2013) .........................................................................44

\section{List of Boxes}

Box 1. Characteristics of farms in the EU-27

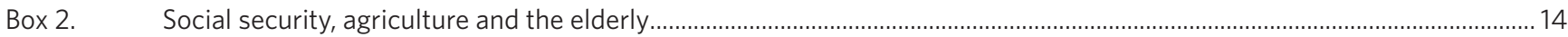

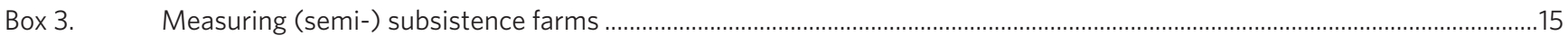

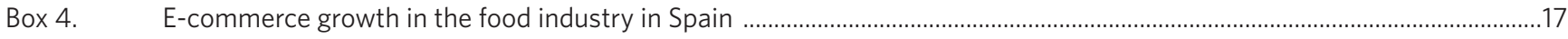

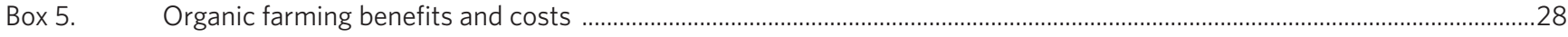

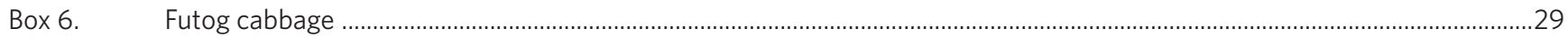

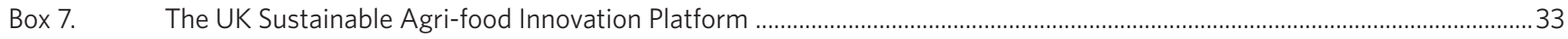

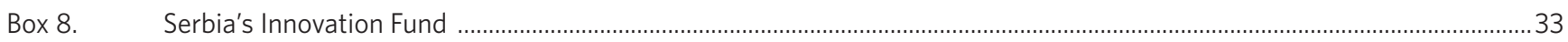

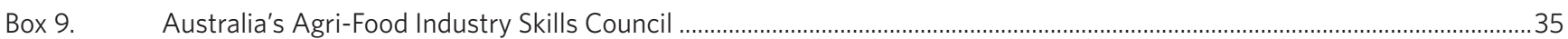

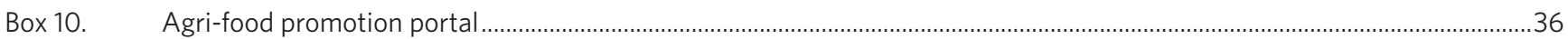

Box 11. E-commerce - A promise unfilled for the agri-food industry? ............................................................................................

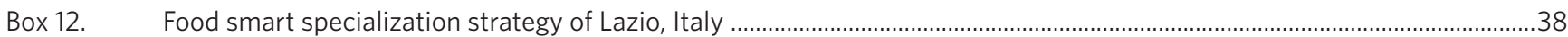




\section{Acknowledgments}

This Regional Study was led by Irina Schuman and Svetlana Edmeades, and comprises a team of World Bank staff, including Bekzod Shamsiev, Daniel Gerber, David Treguer, Luc Christiaensen and Meeta Sehgal. The task was managed by Julian Lampietti and has benefited by peer-review comments received from Sergiy Zorya, Parmesh Shah and Joao Pedro Wagner de Azevedo. The team is grateful for the analysis and inputs provided by Johan Swinnen, Maria Garrone and Hannah Ameye (KU Leuven), Philip van der Celen (FAO) and Demetris Psaltopoulos (University of Patras). The study has benefited from the strong collaboration with staff of the Ministries of Agriculture in the six Western Balkan countries. 


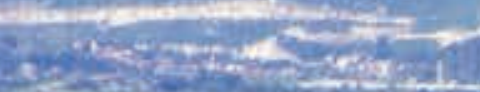

xis



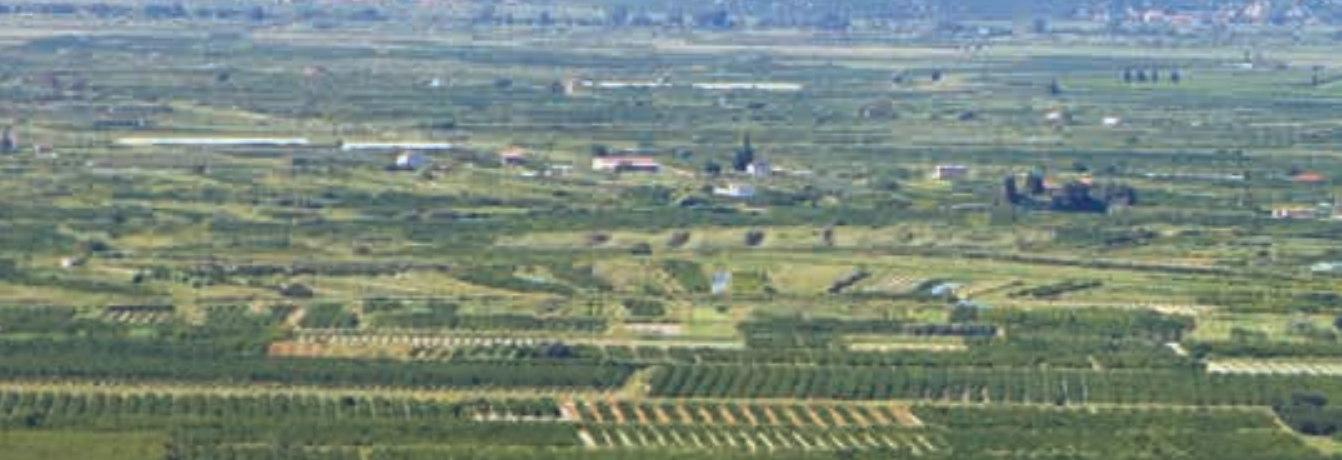
7)

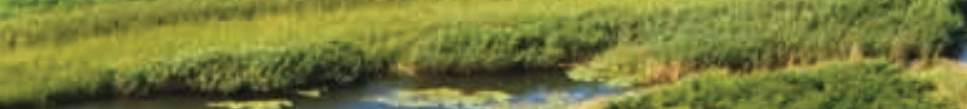



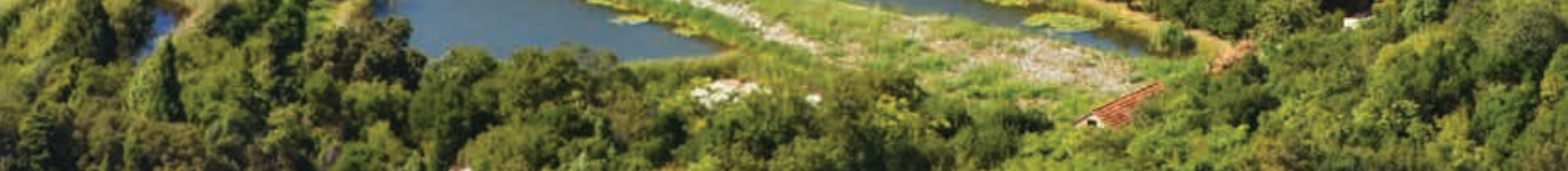




\section{Executive Summary}

1. The agri-food industry-comprising agricultural inputs, primary agricultural production, off-farm food processing, food distribution, food retail and consumption, and other food-related services-is one of the most important industries in the Western Balkans in terms of turnover, jobs and geographic scale. Average turnover of the agri-food industry accounts for 24 percent of total manufacturing turnover in the Western Balkan (WB) region compared to the European Union (EU) average of 15 percent (in 2011) and it is more evenly distributed geographically than other industries. Global evidence suggests that agribusiness has the highest short-term indirect employment impact, where creating one job generates more than double the number of jobs in the rest of the economy. The sector's broad geographic footprint, multiple functions and cross-sector linkages could transform the industry into a powerful driver of value addition, income diversification and innovation in rural areas.

2. The Western Balkans have both the productive assets and the market opportunities to transform their agri-food industries into engines of growth and jobs. The agri-food industry has experienced positive growth in recent years (an estimated average annual growth rate of 11.9 percent in the period 2006-2011 compared to the EU average of 4.4 percent) thanks in part to its gradual integration to regional markets. In the next decade, the ongoing transition process of the agri-food industry will be further shaped by shifting consumer demand, increased weather risks, food quality requirements and new sustainability commitments undertaken by governments, businesses and investors. In this rapidly changing environment, WB countries can respond by diversifying regional offerings of high-value agri-food products and related services and capitalizing on related jobs.

3. The economic impacts of the agri-food sector are significant for jobs and growth. The input-output analysis carried out for this report finds that, in Albania, the agri-food industry is responsible (directly and indirectly) for almost half of the economy-wide jobs, while in the Republic of North Macedonia (where the economy has already embarked in a diversification process) it creates nearly a third of employment. The economic impacts of direct support to farmers 
(under Pillar 1 of the Common Agricultural Policy, CAP) are not negligible, but in the case of Albania, support allocated under rural development programs (Pillar 2 of CAP) has double the effect on increases in employment (which grows 13 percent), with farm modernization and food processing being important generators of jobs due to their labor intensity. The findings also point to the importance of pursuing policy initiatives which facilitate strengthening of economic interdependence in the food chain and rural areas. For example, in North Macedonia, if the agri-food sector doubles its purchases of domestically-produced farm products, employment in the economy increases by 21 percent, also rising output and value added by 16 percent.

\section{Small farm size, low skilled labor, depopulation of rural} areas and limited market participation are important obstacles to modernizing the primary sector. With an average farm size raging between 1 ha (in Albania) and 5 ha (in Serbia and Montenegro) and many (35 to 40 percent) agricultural producers in the region being semi-subsistent, selling surplus production to local markets, production at scale, innovation and integration are not possible. Yet, despite the depopulation of rural areas, around half of the region's residents live in such areas, a share larger than the EU-28 (around 26 percent). However, the skills of the primary agriculture labor force are limited due to low educational levels and lack of opportunities for training. Although in some countries (Serbia, Albania, Montenegro) a third of the agricultural workers are above 65 years of age, the age composition of the labor force is much younger in Kosovo, North Macedonia and $\mathrm{BiH}$. With age and educational levels being highly correlated with the possibility of moving from agriculture into service-based activities, it is imperative that training programs are designed to support the modernization needs of the sector on and off farm. Unless these are tackled, the agri-food industry will continue to underperform in terms of its contribution to generating added value, diversifying rural economies and raising rural incomes.

\section{The limited amount of foreign direct investment in the} agri-food industry in the region is another constraint to competitiveness. In the new member states of the EU, foreign investment in the agri-food industry was the most prominent contribution to productivity growth, quality improvements and enhanced competitiveness in the agricultural sector. In the Western Balkans, the agri-food industry remains significantly underrepresented in foreign direct investment (FDI) compared to its share in total manufacturing turnover. Whereas the sector accounted for 24 percent of total manufacturing turnover, its share in total manufac- turing FDI in 2010 was only 15 percent. Direct investments can be an effective vehicle for the transfer of technology and know-how to the region. The design and promotion of FDI incentive schemes are not fully developed and strategic investor targeting is still an emerging practice.

6. To overcome these challenges and to advance their development agendas in the context of EU-accession and beyond, WB countries must consider "farm to fork" intervention approaches that are centered on promoting compliance with international food safety and quality standards, facilitating well-functioning agri-food value chains, incentivizing innovation and entrepreneurship, and building sector-specific human capital, as well as promoting foreign direct investment and trade. In addition, given that the agrifood sector alone is unlikely to absorb all the surplus labor in rural areas, facilitating the integration of modern agri-food value chains inside diversified and knowledge-based rural economies will be critical for long-term success. A shift of policy towards rural diversification investment should be gradually but decisively attempted. This is because a more-diversified rural economy would facilitate the absorption of surplus farm labor and, in parallel, contribute to the enhancement of economic linkages in rural areas and enable a reverse of rural decline.

7. Public policies enabling private sector development and participation are critical for job creation. Developing an enabling business environment and investment climate that help transform the agri-food industry into a competitive provider of a diverse offering of high-value agri-food products must be the focus of government interventions. Policy and institutional reforms could be organized around the following core components: (i) Providing smart incentives to producers and agribusinesses; (ii) Delivering core public goods in rural areas; and (iii) Building effective institutions. Increased private sector investment and innovation are also required to capitalize on the value addition potential of the agri-food industry. Building human capacity that responds to the new dynamics of the agri-food industry is critical for capturing the job creating potential.

8. Information technology is the new variable in the transformation equation. It can play an important role in bringing knowledge to producers and supporting the process of strengthening extension services and food quality control. It can be the link between producers and consumers, and rural and urban areas, where road infrastructure is not sufficient and production units are geographically dispersed. It can be an aggregating factor in a context of 
fragmented land and weak land markets. It can play an important role in capital and labor mobility. And for all it can be, it requires jobs and training to unlock the potential of the agri-food industry. These jobs up the agri-food system are likely to be taken by the WB youth in both rural and urban areas. 


\section{Study Objectives and Scope}

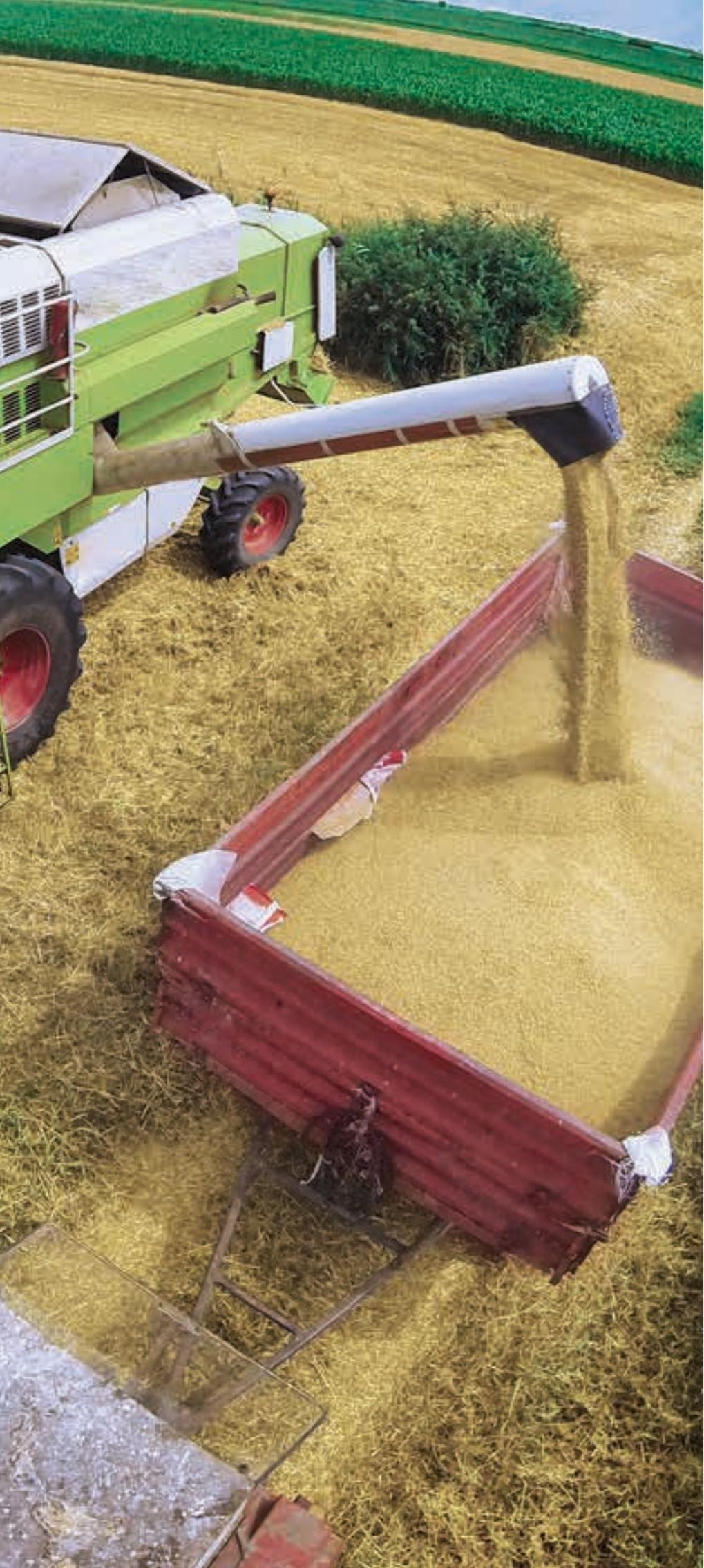

9. The objective of this regional study is to examine how further investment, modernization and transformation of the agriculture and rural economy can contribute to job creation and economic growth in the Western Balkans, while highlighting how better public policies and deeper European integration can help take this process forward. The study aims to better understand the features of agri-food employment in the region, including its potential to generate more, better and more inclusive jobs and to identify transformative (policy) actions that could trigger a structural change towards a more productive use of human and other resources in agriculture.

10. The study is expected to inform the policy dialogue in the agriculture and rural sector in the region, in a way complementary to the more specific financial and technical support that the EU is providing through its dedicated Instrument for Pre-Accession Assistance (IPA).

11. The study focuses on the Western Balkans, a region comprising six EU pre-accession countries: Albania, Bosnia and Herzegovina $(\mathrm{BiH})$, Kosovo, North Macedonia, Montenegro and Serbia.

12. The study uses information and data about agriculture and related factors which, for the most part, is publicly available. As none of the Western Balkans has fully harmonized its agricultural statistics with EU standards and Eurostat rules, direct comparisons of the data and indicators between the countries is not always possible. The study relies on a combination of quantitative and qualitative methods for the analysis.

13. Considering the important forward and backward linkages that agriculture brings about and its related job creation potential, the sector is considered broadly as an agri-food system in which both on-farm production (primary sector), output and food processing (agribusiness) and related services for input provision and output delivery are considered. This enables a more integrated perspective to job creation potential. 
14. The World Development Report (WDR) $2013^{1}$ defines jobs as "activities that generate income, monetary or in kind, without violating human rights", internalizing both job creation and enhancing job quality. In line with this definition, the study discusses the employment generating potential in the agri-food system, while also touching on job quality aspects, such as productivity and well-being. There are common challenges across countries based on their level of development, demography, endowments and institutions-how to make agricultural jobs more productive and create job opportunities outside farms; how to find ways to diversify exports, so that jobs are connected to global markets rather than supported through government transfers; how to design social protection systems in ways that extend coverage without penalizing employment (WDR, 2013). All these challenges are true for the Western Balkans.

1 World Bank. 2013. World Development Report: Jobs for Development. 

TABLE 1. MACROECONOMIC INDICATORS, WESTERN

BALKANS, 2015

\begin{tabular}{|l|c|c|c|}
\hline Country & $\begin{array}{c}\text { Agricultural } \\
\text { GDP } \\
\%\end{array}$ & $\begin{array}{c}\text { Agriculture } \\
\text { employment } \\
\%\end{array}$ & $\begin{array}{c}\text { Rural } \\
\text { population } \\
\%\end{array}$ \\
\hline Albania & 22.05 & 41.27 & 42.59 \\
\hline BiH & 7.10 & 17.88 & 60.23 \\
\hline Kosovo & 13.73 & 2.24 & 60.00 \\
\hline North Macedonia & 11.16 & 17.86 & 42.90 \\
\hline Montenegro & 10.20 & 7.71 & 35.97 \\
\hline Serbia & 9.46 & 19.41 & 44.45 \\
\hline EU-28 & 1.56 & 4.19 & 25.20 \\
\hline
\end{tabular}

Source:WDI, The World Bank (2016), Eurostat (2016), Kosovo Green Report (2015).

12 percent This has implications for the measurement of labor productivity and comparisons across sectors, considering the variations in hours worked within the sector.

18. The agri-food industry is the most important manufacturing industry in the Western Balkans in terms of turnover and employment, as well as geographic footprint in rural areas. The agri-food industry accounts for the largest share of manufacturing industry turnover in the WB region. Average turnover of the agri-food industry in 2011 accounted for 23.8 percent of total manufacturing turnover in the WB region compared to the EU average of 15.4 percent (Figure 2). The sector is most significant in Serbia (31.5 percent), followed by $\mathrm{BiH}$ (22.9 percent), North Macedonia (22.8 percent) and Albania (18.2 percent). Importantly, agri-food industry turnover is more evenly distributed geographically than other manufacturing sectors such as automotive production (see Figures 3.A and 3.B), which underlines the unique role that agri-food industry development can play in promoting growth and jobs in rural areas. Average employment in the agri-food industry amounted to 16.9 percent of total manufacturing jobs in the WB region in 2011, compared to the EU average of 14.9 percent (see Figure 4). Whereas the sector accounts for large shares of manufacturing employment in North Macedonia (19 percent) and $\mathrm{BiH}$ (17.5 percent), its share is smaller in Albania (14.3 percent).

\section{Employment intensity}

19. Unemployment rates in the Western Balkans are high. In Kosovo unemployment was very high throughout 20062015, although it fell from around 45 percent in 2006 to around 33 percent in 2015. Serbia's unemployment rates fluctuated between 10 and 25 percent from 2006 to 2015 . North Macedonia's unemployment rate has steadily decreased from about 38 percent in 2006 to 28 percent in 2015. Montenegro's unemployment rate has been around 20 percent in recent years. BiH's unemployment rate declined and stabilized to around 28 percent in 2015. Overall, Albania's unemployment rates are the lowest, but still fluctuate between 12 and 18 percent. Youth and rural residents

\section{FIGURE 1. WHILE MOST COUNTRIES IN THE REGION ARE IN A PROCESS OF TRANSITIONING OUT OF AGRICULTURAL BASED ECONOMIES, ALBANIA CONTINUES TO HEAVILY DEPEND ON ITS RURAL ECONOMY}

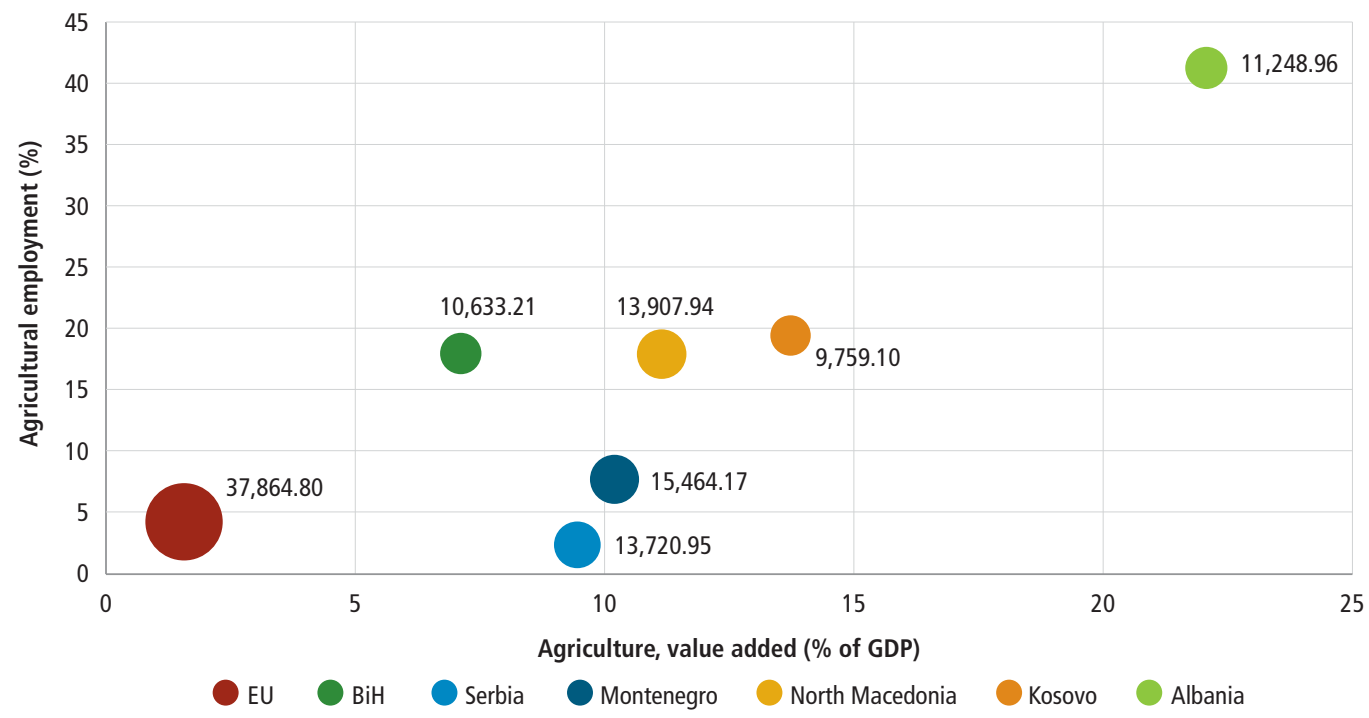

Source: World Development Indicators (2016); Eurostat (2016).

Note: The size of the circles reflects the size of GDP per capita (current international dollars). 


\section{FIGURE 2. THE SHARE OF FOOD, BEVERAGE AND TOBACCO MANUFACTURING TURNOVER OF TOTAL MANUFACTURING TURNOVER IS LARGE IN THE WESTERN BALKANS, 2011}

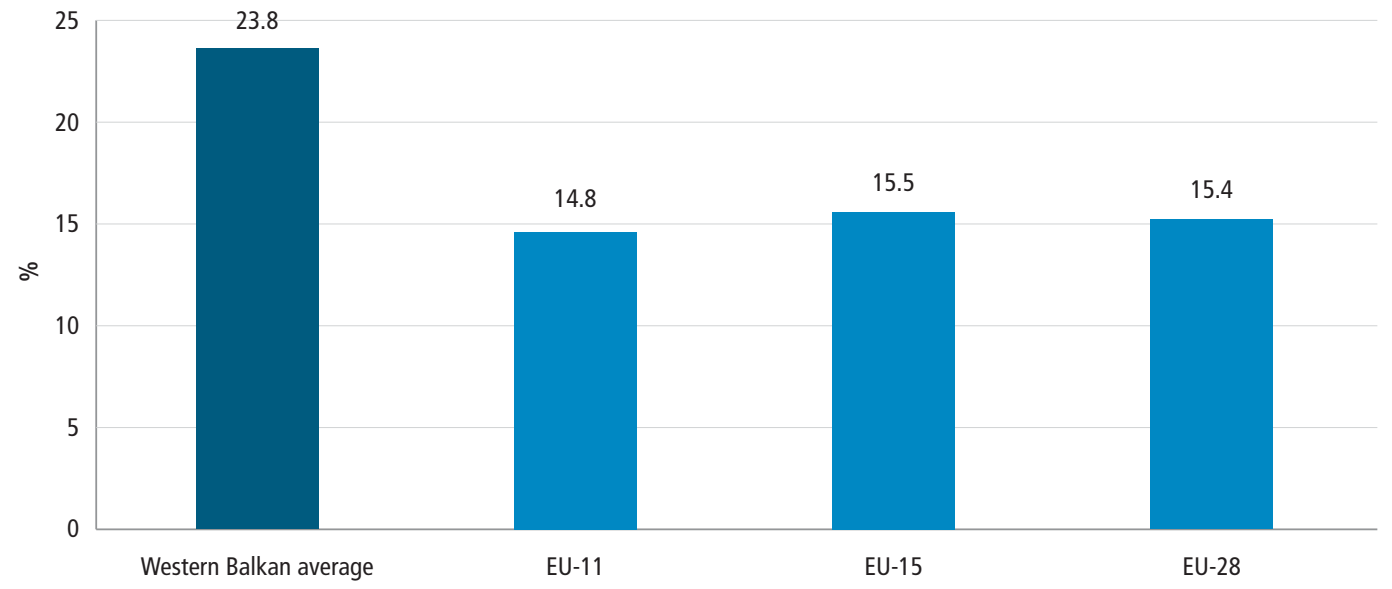

Source: UNIDO

Note: No data available for Kosovo and Montenegro.

FIGURE 3.A. CONCENTRATION OF FOOD AND BEVERAGE MANUFACTURING IN CEFTA*, 2008-2010

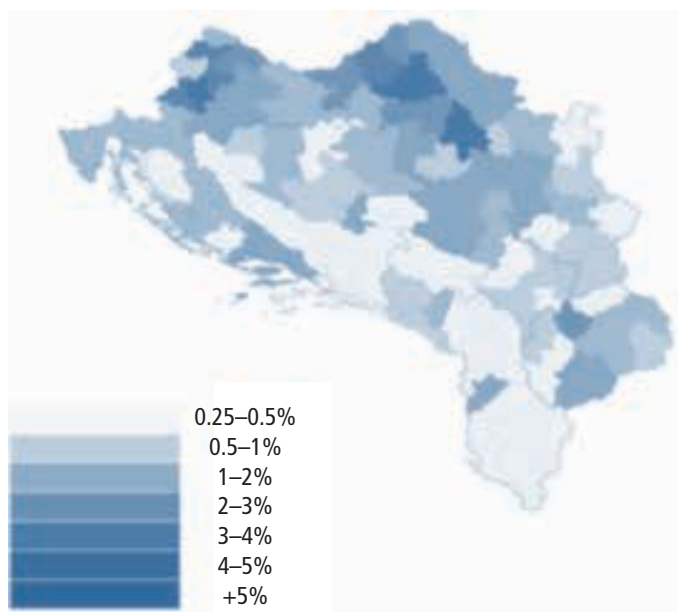

FIGURE 3.B. CONCENTRATION OF MOTOR VEHICLES MANUFACTURING IN CEFTA*, 2008-2010

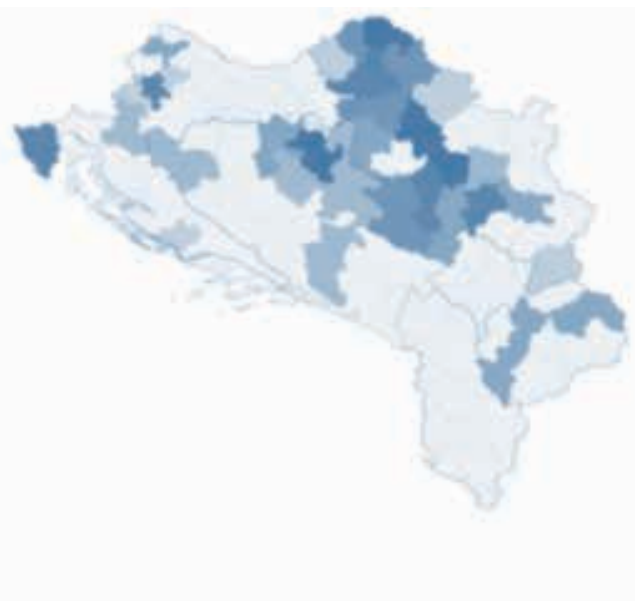

Source: OECD, CEFTA (2013). Industry Concentration and Country Specialisation in CEFTA. CEFTA Issues Paper 5, OECD Publishing, Paris, p30, p47.

Note: The map shows the share of sector turnover in each sub-national region of the Western Balkans. The shares do not add up to $100 \%$ because CEFTA includes Moldova (not shown on the maps).

are among the most affected by the lack of gainful employment opportunities.

20. Informality in the sector is significant, suggesting that labor absorption by the sector is broader than that measured in the formal labor market. In countries like Serbia and Albania, where such data is available, a much larger proportion of the agricultural workforce is engaged in informal agricultural employment compared to the non-agricultural sectors. In 2013, 87 percent of the Albanian agricultural workforce had an informal job, compared to 43 percent of the non-agricultural workforce. The gap is wider in Serbia where, in 2014, the share of informal employment accounted for 67 percent of total agriculture employment, compared to 8.9 in non-agricultural sectors (ILO, 20164).

21. The net effect of labor mobility is not clear due to the complexity of the dual (formal and informal) labor dy-

4 ILO. 2016. International Labor Organization database. 


\section{FIGURE 4. THE SHARE OF FOOD, BEVERAGE AND TOBACCO MANUFACTURING EMPLOYMENT IN TOTAL MANUFACTURING EMPLOYMENT IS IMPORTANT, 2011}

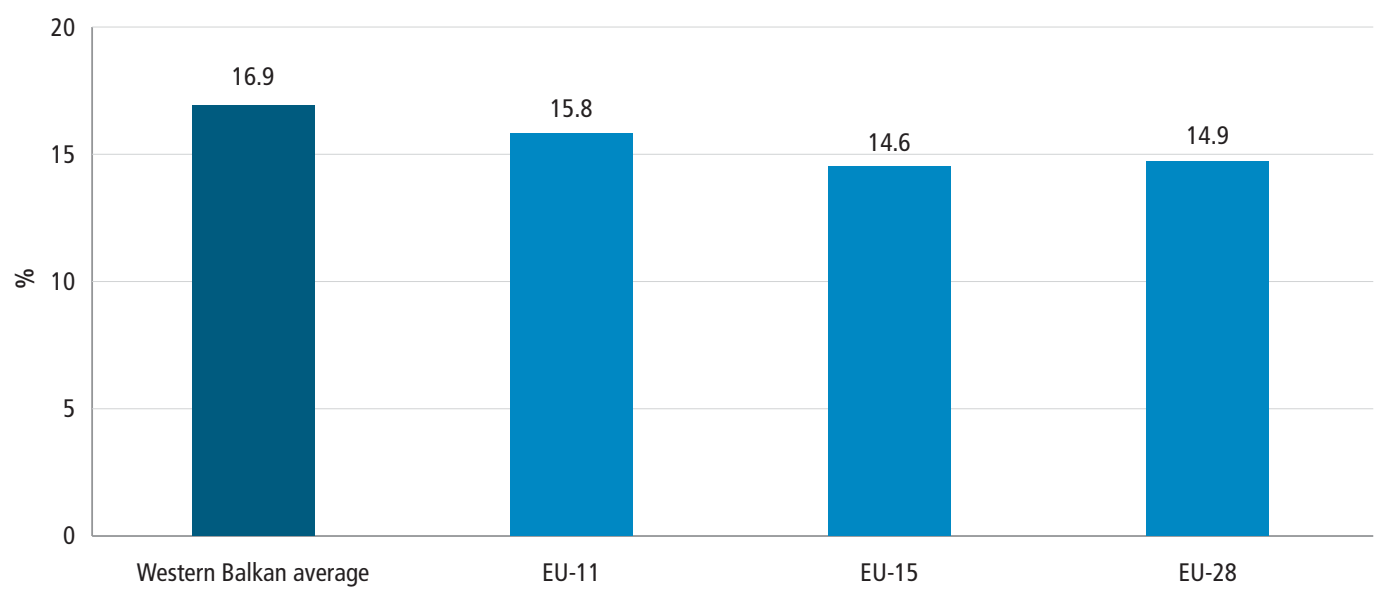

Source: UNIDO.

Note: No data available for Kosovo and Montenegro.

namics in the sector. On the one hand, it was believed that during the economic transition in the region, there were significant outflows of labor from agriculture, as returns of labor in other sectors increased (e.g., Bofinger, 19935; Brada, 19896; Jackman, 19947). Between 2011 and 2015, Albania reported the largest decline in rural population (4.0 percent), followed by $\mathrm{BiH}$ (2.6), Kosovo (2.3) and North Macedonia (0.9). In the EU-28, the share of agricultural employment was relatively stable at around 4 percent (Eurostat, 2016). On the other hand, agriculture continued to play a buffer role by absorbing labor laid off in other sectors (e.g., Leiprecht, 19998; Seeth et al., 1998). Although the share of the rural population in the Western Balkans has significantly decreased over the last 50 years, in 2015, this share (about 49 percent) was still much larger than in the EU-28 (around 26 percent). In Kosovo and $\mathrm{BiH}$ more than half of the total population still lives in rural areas (an estimated 60 percent). In North Macedonia, Albania and Serbia the average share of people living in rural areas is between $42-44$ percent of the total population, with
Montenegro having the smallest share in the region of people living in rural areas (36 percent).

22. Labor productivity in the region has increased, driven mainly by rural outmigration. Over the past decade, agricultural labor productivity (agricultural value added per farm worker $)^{10}$ has significantly increased in the Western Balkans; more so than in the EU-28 (Figure 5). The increments in agriculture labor productivity range from 45 percent in Albania to 107 percent in $\mathrm{BiH}$. Montenegro and North Macedonia's productivity growth is 73 and 64 percent, respectively. Serbia has a slightly lower productivity growth than the EU-28 with 45 percent compared to 52 percent. However, in Albania, the inter-sectoral and spatial shift away from agriculture in the 2000s did not lead to notable gains in aggregate productivity or formal employment growth in this period (World Bank, 2015'11).

23. Low educational levels and age composition of those in primary production challenge the modernization of the

\footnotetext{
5 Bofinger, P. (1993). "The Output Decline in Central and Eastern Europe: A Classical Explanation," Discussion Paper Series. Center for Economic Policy Research. London.

6 Brada, J. C. (1989). "Technical Progress and Factor Utilization in Eastern European Economic Growth," Economica 56 (1989), $433-448$.

7 Jackman, R. (1994). Economic Policy and Employment in the Transition Economies of Central and Eastern Europe: What Have We Learned? International Labor Review 133, no. 3 327-345.

8 Leiprecht, I. (1999). "Sectoral Change out of the Agricultural Sector in Poland," Unpublished manuscript.

9 Seeth, H. T., S. Chachnov, A. Surinov, and J. von Braun (1998). "Russian Poverty: Muddling through Economic Transition with Garden Plots," World Development 26, no. 9, 1611-1623.

10 As defined by the World Bank: "Agriculture value added per worker is a measure of agricultural productivity. Value added in agriculture measures the output of the agricultural sector (ISIC divisions 1-5) less the value of intermediate inputs. Agriculture comprises value added from forestry, hunting and fishing as well as cultivation of crops and livestock production." Data are in constant 2010 USD.

11 World Bank. 2015. Next Generation Albania. Systematic Country Diagnostic.
} 


\section{FIGURE 5. INDEX OF AGRICULTURAL LABOR PRODUCTIVITY GROWTH FOR THE WESTERN BALKANS, 2006=100}

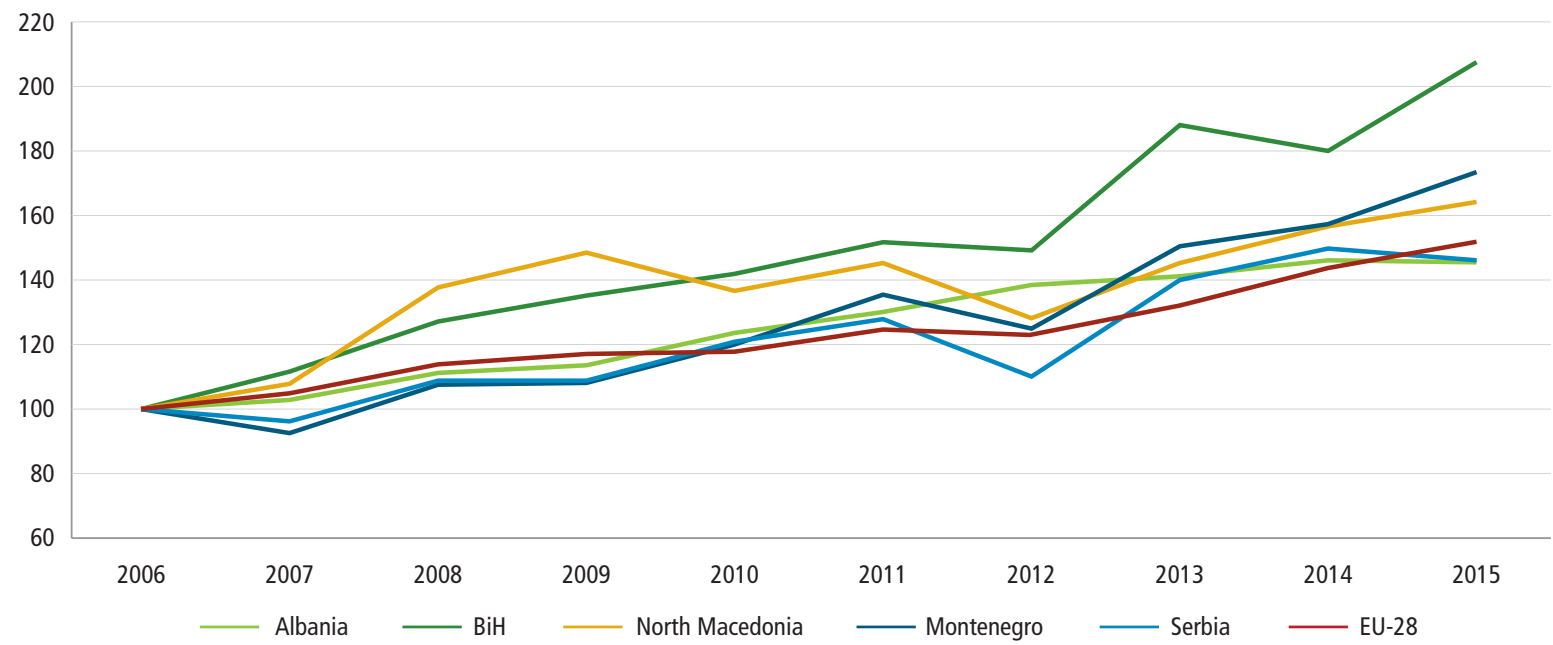

Source: Calculations from World Development Indicators, World Bank (2016).

sector. Kosovo and North Macedonia have a relatively young agricultural labor force compared to the other WB countries. Almost one third of the agricultural holders in Kosovo and more than 40 percent in North Macedonia were under 45 years of age in 2013. In both federal states of $\mathrm{BiH}$ the largest share of people working in the agricultural sector is between 45 and 54 years, while the share of workers above 65 is extremely low (less than 1 percent). In Albania, Serbia and Montenegro a third of agricultural workers are above 65 years of age. Many agricultural workers have not completed primary or secondary school and some have no formal education. A reduction of skills in the agricultural labor force is due to aging, migration and lack of opportunities for education and training of new entrants.

24. Inadequate human capital is a key constraint for agricultural labor restructuring, as well as business development and economic activities in rural regions (Swinnen and Ciaian, 2008'2). Studies have shown that age and educational levels are highly correlated with the chance of finding a job in various sectors, such as the industrial sector, services, business start-ups and non-agricultural activities in rural areas. In Slovenia, younger and more educated people are more likely to move from agriculture into service-based activities (Bojnec and Dries, 2005'3). General labor market policies as well as those targeted to the rural areas, includ- ing vocational training programs, are very important. Those training programs will not only tackle the unemployment level, but also improve the production standards in different sectors including agriculture.

25. The average farmer is of old age and low education in the broader European context. In Portugal, Spain, Italy, Greece and Malta the percentage of people who achieved at least upper-secondary education in rural regions ranges from 27 percent (Portugal) to 51 percent (Italy). Only 1 percent of adults in the rural regions of Bulgaria and Romania participated in education or training activities in 2012 (European Commission, 2013 14 ). In the EU-27 almost one third of the farmers is older than 65 years (Box 1).

26. The structural challenges facing the agri-food industry currently limit its potential contribution to growth and decent jobs. The agri-food industry in the Western Balkans underperforms today as a potential engine for growth and higher incomes in rural areas. In 2011, average value added generated per employee in the agri-food industry in the Western Balkans was equivalent to only 23.6 percent of the EU-28 average (Figure 6), whereas agri-food industry salaries equaled only 15.4 percent of the EU-28 average (Figure 7). In order to transform the agri-food sector into an engine

12 Swinnen, J. and Ciaian, P. (2008). Growth, competitiveness and convergence in Romanian agriculture. Agricultural Economics and Rural Development, 5 (3-4), 143-160.

13 Bojnec, Š. and L. Dries (2005) 'Causes of changes in agricultural employment in Slovenia: evidence from micro-data', Journal of Agricultural Economics, Vol. 56(3), pp. 399-416.

14 European Commission, (2013). Rural Development in the EU: Statistical and Economic Information. Report. Directorate-General for Agriculture and Rural Development (DG AGRI).. 


\section{BOX 1. CHARACTERISTICS OF FARMS IN THE EU-27}

- Close to one third of all farmers are above the normal retirement age of 65 in 2013.

- The overall ratio of young (below 35 years) to elderly (over 55 years) farmers came to 0.11 in 2013, meaning that for every young farmer, there were 9 elderly farmers.

- In 2013, 42 percent of all farmers worked full-time.

- Roughly 75 percent of agricultural labor was provided by family members in 2013.

- Large farmers accounted for 3.1 percent of all farms in 2013.

- Farms with less than 20 ha of utilized agricultural area accounted for almost 9 out of 10 (86.3 percent) farms in the EU and for more than two thirds (68.1 percent) of the labor force directly working on farms.

Source: European Commission 2015 and 2016. ${ }^{15}$

of growth and decent jobs, governments in the WB region must consider a multi-pronged strategy aimed at developing an enabling business environment and investment climate that are conducive to compliance with international quality standards, well-functioning value chains, innovation and entrepreneurship, foreign direct investments and trade, as well as sector-specific human capital development. Given that agri-food industry growth alone will not be able to absorb all the surplus labor in rural areas, diversifying economic opportunities in rural areas must be a critical component of any development strategy in the region.

27. Key knowledge and skills gaps impede high productivity levels of the agri-food industry in the Western Balkans. According to the World Bank's 2015 Business Environment and Enterprise Performance Survey (BEEPS) survey, 58 percent of firms across sectors in the Western Balkans reported that the skills and the education of workers are a problem for doing business. The agri-food industry faces particular challenges in attracting staff with advanced skills that are not typical for the sector (e.g. ICT, genetics, behavioral science, etc.). Given that the agri-food industry is generally not considered an attractive sector by young people, the most economically active and educated segments of the population are usually underrepresented in it. Furthermore, agricultural schools and faculties in the WB region focus mainly in providing their students with production-level knowledge and skills that are tailored to the needs of large-scale production systems. They also operate as stand-alone units, which limits inter-disciplinarity and cross-fertilization. ${ }^{16}$ As a result, smaller producers

\section{FIGURE 6. THE AVERAGE VALUE ADDED PER EMPLOYEE IN THE FOOD, BEVERAGE AND TOBACCO MANUFACTURING INDUSTRY IS VERY LOW, 2011}

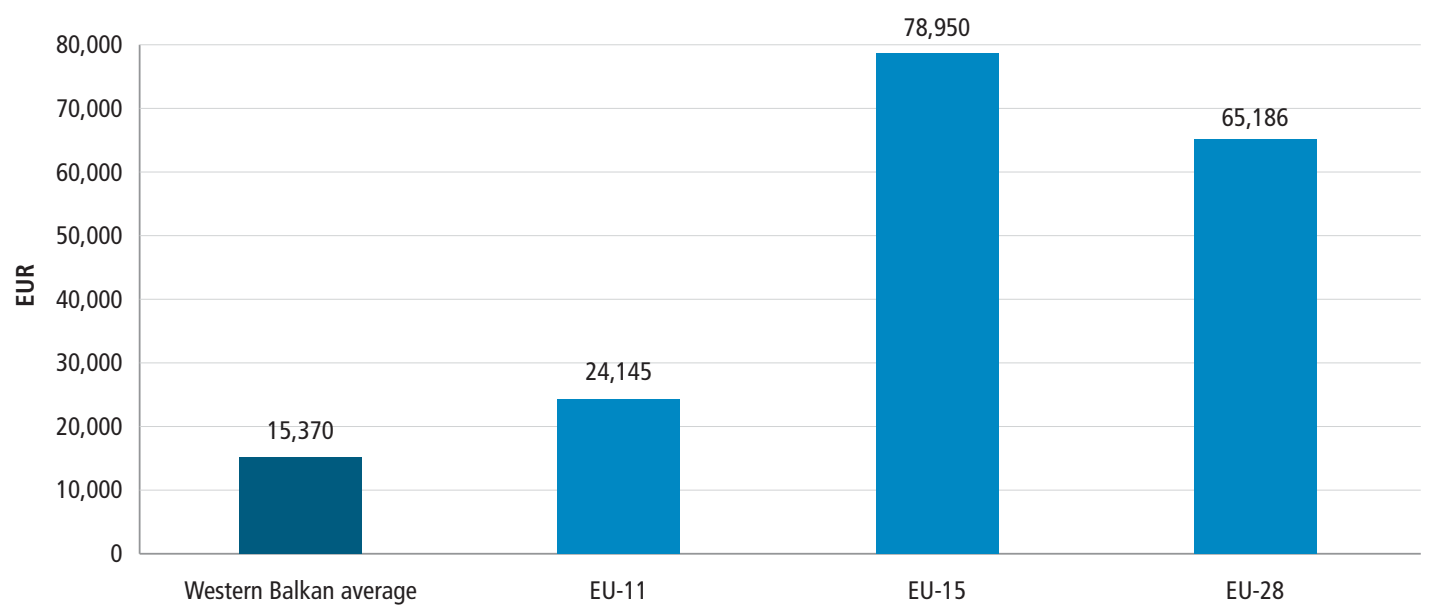

Source: UNIDO.

Note: No data available for Kosovo and Montenegro.

15 European Commission. 2015. EU Farms and Farmers in 2013: an Update. EU Agricultural and Farm Economics Briefs No. 9 November European Commission (2016). Agriculture, forestry and fishery statistics 2016 edition. Directorate-General for Agriculture and Rural Development (DG AGRI). 16 Grozdanic, R. (2013). Agribusiness and Agro-Industrial Strategies, Policies and Priorities for Achieving Higher Competitiveness, Employability and Sustainability in the Western Balkans Region, Friedrich Ebert Stiftung and European Federation of Food, Agriculture and Tourism Trade Union (EFFAT), Belgrade, p81. 


\section{FIGURE 7. THE AVERAGE WAGES AND SALARIES IN THE FOOD, BEVERAGE AND TOBACCO MANUFACTURING INDUSTRY ARE VERY LOW, 2011}

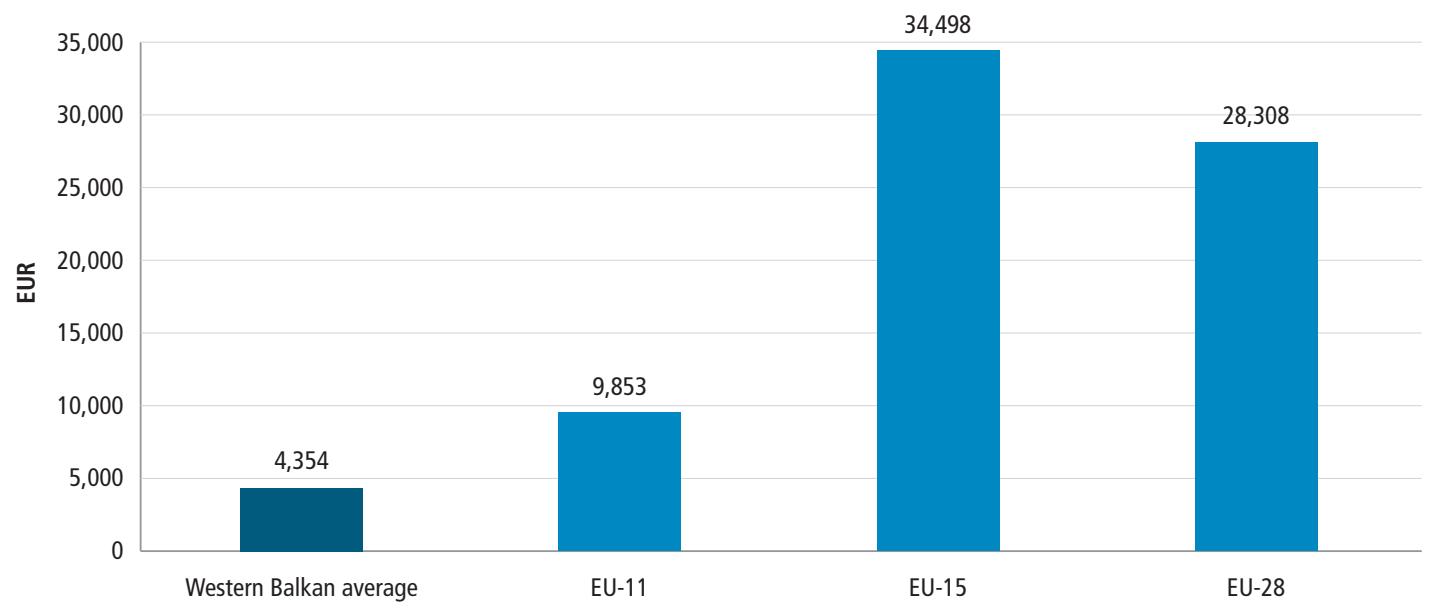

Source: UNIDO.

Note: No data available for Kosovo and Montenegro.

as well as agri-food small and medium enterprises (SMEs) in particular face important knowledge and skills gaps in areas such as business management, quality management, logistics, financial literacy, as well as (international) marketing. Lastly, vocational education and training (VET) schemes, in particular work-based learning schemes, remain underdeveloped and lack collaboration with businesses. For example, legal frameworks regulating internships and apprenticeships are not in place in most countries. ${ }^{17}$

\section{Productive inclusion}

28. Rural poverty is a problem in all the WB countries, as farming systems are only developing in more favorable areas and in the vicinity of urban settlements (Volk et al., 2017'18). In Albania, due to the decelerating pace of economic growth post-2008, accompanied by a contraction of the demand for labor (in construction), poverty increased between 10 and 30 percent in rural areas (World Bank, 2015 ${ }^{19}$ ) There is not a unique pattern across Albania in terms of poverty and sector of employment concentration of the population. ${ }^{20}$ In the same period, growth in Montenegro has been accompanied by increased poverty, with rural poverty reaching 55 percent in 2012, but increasingly concentrating in urban areas in more recent years, and with agricultural income exhibiting the highest level of volatility for the poor (World Bank, 201621).

29. Inequity can be costly. It can substantially impair certain groups' upward economic mobility prospects, as well as the economic growth potential of the region. Specifically, differences in labor market activity rates between men and women are estimated to lead to potential economic losses averaging around 18 percent of GDP in the WB region, and as high as 28 percent in Kosovo. ${ }^{22}$ Similarly, prevalent unemployment of youth across the Western Balkans can have long-lasting effects since joblessness at a young age tends to delay or prevent the accumulation of valuable on-the-job skills, translating into lower productivity and human capital accumulation for young workers later in life. ${ }^{23}$ Population aging in most of the region adds further urgency to the need for more participation of all groups in the workforce.

30. Women represent a high share of agricultural labor. In 2015, the majority of formal workers in agriculture in the region were male (64 percent). Albania reports the highest share of women employed in the agricultural sector (49.5 percent), followed by Montenegro (48 percent), North

17 OECD. 2016. Competitiveness in South East Europe: A Policy Outlook, Competitiveness and Private Sector Development, OECD Publishing, Paris, p103.

18 Volk et al. (2017). Monitoring of Agricultural Policy Developments in the Western Balkan Countries. JRC Technical Reports.

19 World Bank. 2015. Next Generation Albania. Systematic Country Diagnostic.

20 World Bank. 2016. Portraits of Poverty and Inequality in Albania.

21 World Bank. 2016. Montenegro: Achieving Sustainable and Inclusive Growth Amidst High Volatility. Systematic Country Diagnostic.

22 Cuberes and Teignier (2015).

23 World Bank. 2016. 
Macedonia (39.1 percent), Serbia (36.2 percent) and $\mathrm{BiH}$ (35.1 percent). Kosovo's share of female participation in agriculture is by far the lowest at 10.4 percent. In Albania and Serbia, female workers represent 80 percent of all informal workers in agriculture (ILO, 2016 24 ).

31. A small average farm size remains a key characteristic of WB agriculture. Small-scale farms survived under communism, except in Albania, the only WB country that was not part of the former Yugoslavia and where large-scale farms dominated during that time. Albania experienced the most dramatic collapse of large-scale farming in all of Eastern Europe and Central Asia (ECA) with a complete shift to small-scale family farming in the 1990s (Cungu and Swinnen, 199925). The average farm size ranges from less than 2 hectares (ha) in Albania and North Macedonia to around 5 ha in Montenegro and Serbia (Table 2). Compared to the EU-28 average (16.1 ha per farm in 2013), the average farm in the Western Balkans is almost three (Serbia) to ten times (Albania) smaller. In terms of distribution, the proportion of farms smaller than 2 ha is particularly high in Montenegro (73 percent) and Kosovo (63 percent) (Table 3). In Serbia, the proportion is smaller and close to the EU-28 average (around 50 percent), even though large-scale

TABLE 2. AVERAGE SIZE OF AGRICULTURAL HOLDING (HA) AND NUMBER OF AGRICULTURAL HOLDINGS

\begin{tabular}{l|c|c}
\hline Country & $\begin{array}{c}\text { Average holding } \\
\text { size (ha) }\end{array}$ & $\begin{array}{c}\text { Number of } \\
\text { holdings }\end{array}$ \\
\hline Albania (2014) & 1.16 & 352,315 \\
\hline BiH & & \\
\hline Kosovo (2014) & $3.18^{26}$ & 129,220 \\
\hline North Macedonia (2013) & 1.85 & 170,885 \\
\hline Montenegro (2010) & 4.50 & 48,870 \\
\hline Serbia (2012) & 5.40 & 631,552 \\
\hline EU-28 (2013) & 16.11 & $10,841,000$ \\
\hline So
\end{tabular}

Source: Albanian Agricultural Statistics (2014), Kosovo Agricultural Census (2014), FYR Macedonia Farm Structure Survey 2013-preliminary data, Montenegro Agricultural Census (2010), Serbia Agricultural Census (2012), Eurostat (2016).

Note: the data for Albania refer to "arable land". farms are mostly concentrated in one region, the Vojvodina Province. Although official data for Albania are not available, there is evidence that more than 65 percent of farms are between 0.5 and 3 ha. (Qineti et al., 2015²7).

32. Land fragmentation is an important land reform topic in the Western Balkans and one that has contributed to the low productivity and competitiveness of the sector in the region (Volk et al., 201728), among other factors. Although land consolidation can bring important economies of scale in production and contribute to growth, the rest of the economy would have to enable the process of job creation and absorption, which will be challenging given the high unemployment rates in the region. With weak credit and land markets, this process of consolidation will take time and, in the short run, small land units can be the only asset that many formal and informal agricultural producers can rely on.

33. Agriculture continues to be an important safety net in the Western Balkans. Households remain in farming as a source of both food and income security (Swinnen et al., 200529), with older people, in particular, using farming to complement small or sometimes inexistent pensions (Box 2) (Swinnen and Ciaian, 2008). Small-scale farming is one of the most common livelihoods for the provision of food security, especially for the elderly. Similar constraints are faced by numerous unemployed younger households. Due to high food prices and slim social payments, few incentives exist for these households to rent out their land to more productive farms (Swinnen and Van Herck, 200930). In many countries in the region, surplus labor was laid off from privatized large-scale corporate farms while small scale family farms absorbed labor in an environment with few alternative employment opportunities (Swinnen et al., 2005). This "smoothing" effect of agriculture employment during the transition period in the Western Balkans is evidenced by the almost constant share of agricultural employment in total employment despite GDP per capita growth (Figure 8), a normally inverse relationship, as in the case of Albania and Kosovo. Coupled with a decline in industrial employment and a modest rise of service sector

24 ILO. 2016. International Labor Organization database.

25 Cungu, A. and Swinnen, J. (1999). "Albania's Radical Agrarian Reform", Economic Development and Cultural Change, Vol. 47, No. 3 (April 1999): 605-61. 26 For Kosovo, the figure on the average holding size is based on the Agricultural Census 2014, which differs from those reported by Bajramović et al. (2016) and Volk et al. (2014).

27 Qineti, A., Rajcaniova, M., Braha, K., Ciaian, P. and Demaj, J. (2015). "Status quo bias of agrarian land structures in rural Albania." Post-Communist Economies 27(4): 517-536.

28 Volk et al. (2017). Monitoring of Agricultural Policy Developments in the Western Balkan Countries. JRC Technical Reports.

29 Swinnen, J.F.M., L. Dries and K. Macours (2005). "Transition and Agricultural Labour." Ag. Econ. 32, 11-20.

30 Swinnen, J., and Van Herck, K. (2009). Agricultural Aspects of Accession to the European Union: Lessons from the EU New Member States and implications for FYR Macedonia. 
TABLE 3. SHARE OF HOLDINGS BY SIZE OF FARMED AREA IN SELECTED WB COUNTRIES, (\%)

\begin{tabular}{|c|c|c|c|c|c|}
\hline Farm size (ha) & Kosovo (2014) & Montenegro (2010) & Serbia (2012) & Farm size (ha) & North Macedonia (2013) \\
\hline$<2$ & 63.22 & 73.41 & 48.83 & 1 to 3 & 58.22 \\
\hline 2 to 5 & 23.28 & 15.61 & 28.90 & 3 to 5 & 29.40 \\
\hline 5 to 10 & 8.28 & 5.55 & 14.11 & 5 to 8 & 2.91 \\
\hline 10 to 20 & 3.19 & 2.37 & 5.12 & 8 to 10 & 0.83 \\
\hline$>20$ & 2.04 & 3.06 & 3.05 & $>10$ & 1.33 \\
\hline
\end{tabular}

Source: Kosovo Agricultural Census 2014, FYR Macedonia Farms Structure Survey 2013-preliminary data, Montenegro Agricultural Census 2010, Serbia Agricultural Census 2012.

\section{BOX 2. SOCIAL SECURITY, AGRICULTURE AND THE ELDERLY}

Montenegro has implemented a social security policy directed mainly at rural households targeting the elderly. The Old Age Allowance Program provides social transfers to rural farmers in the form of pensions. In turn, the aim is to secure an adequate living standard in rural areas. These pensions are provided to the elders of family households, where one elderly member is eligible per household. This policy, however, constitutes around 20 percent of Montenegro's agriculture budget. The financial sustainability of these pension schemes is a problem in the Western Balkans. A high unemployment rate, the large proportion of the population working informal jobs and the exclusion of the self-employed, lead to a large social burden and strain state budgets. Nevertheless, agricultural policy will remain rather limited in terms of reducing overemployment as the process of agricultural employment depends highly on the other income opportunities that do or do not exist. Some policy examples can be found in Poland and Romania, such as the "early retirement schemes". These schemes motivate elderly farmers to stop farming and rent out their land instead. This relieves the problem of overemployment as well as aiding land consolidation.

jobs, the proportion of agricultural employment increased temporarily in most countries of the region and remained at high levels. Agriculture has absorbed fired workers from other sectors or has provided subsistence activity at times when the number of jobs in the formal sector was limited (World Bank, 2003 ${ }^{31}$ ). While economic circumstances have changed considerably over the past 20 years in many transition countries, these factors still can play an important role

FIGURE 8. THE SMOOTHING EFFECT OF AGRICULTURE, 2005-2015

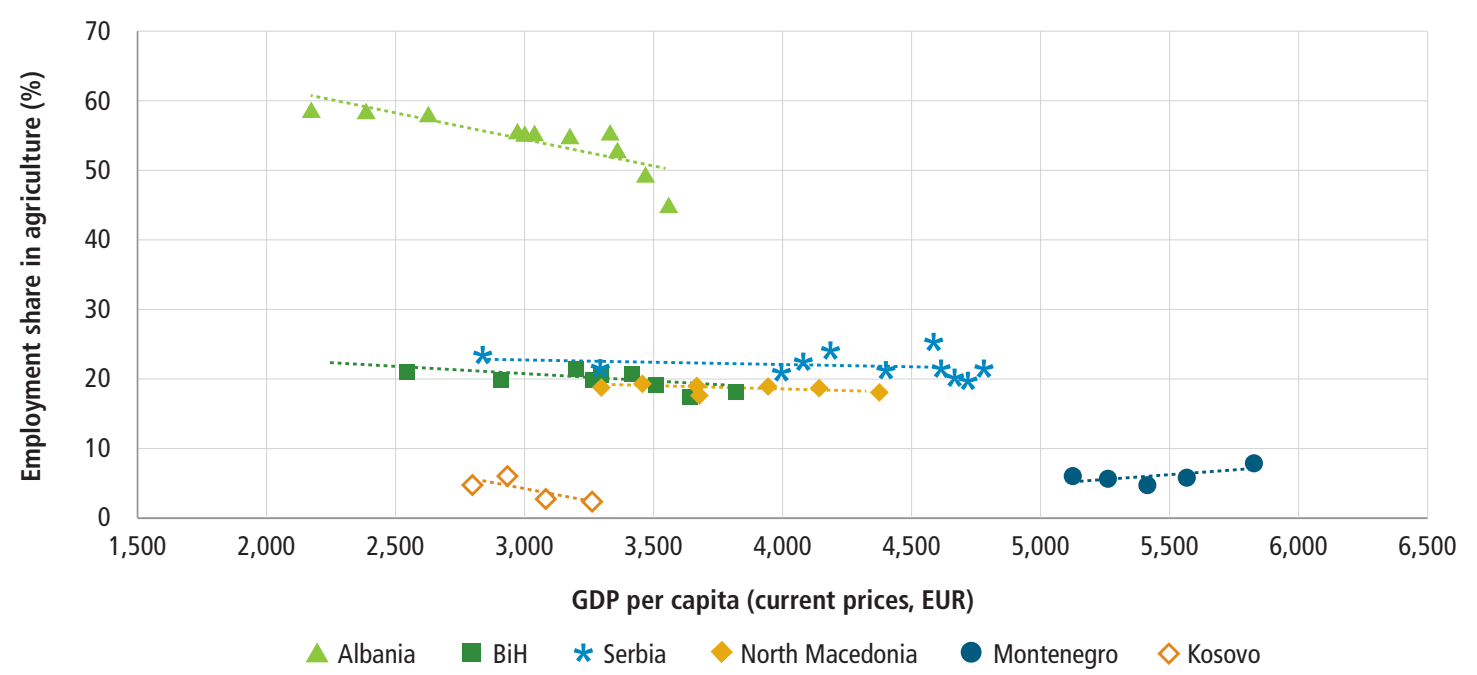

Source: World Development Indicators, World Bank (2016).

31 World Bank. 2003. FYR Macedonia - Country Assistance Strategy. Report No. 26513-MK. Washington, D.C. 


\section{BOX 3. MEASURING (SEMI-) SUBSISTENCE FARMS}

Measuring semi-subsistence is challenging. Semi-subsistence farm households do not keep records of production, consumption or sales, which must be estimated by household members themselves or by third parties (Fritzsch et al., 2010 32 ). Several methods have been used to quantify semi-subsistence farmers. One approach is based on farm size - to reach a marketable level of surplus output, the farmed areas should be above a certain minimum size (Lerman, 200433). McConnell and Dillon (1997) argue that farms between 0.5 and 2 ha could be a good proxy indicator for semi-subsistence farms. However, they also caution about the shortcoming of using farm size as a general indicator, as there are other conditions for defining subsistence farming, such as local land quality and social and economic conditions. Another measure is the Standard Output (SO), measuring the economic size of a farm regardless of its land area. In a study by Davidova et al. (2013) ${ }^{34}$ for the European Parliament, the authors set as the economic size criterion for EU small and semi-subsistence farmers that the standard output must be between 2,000 EUR and 8,000 EUR. In terms of economic size, the farm structure in Montenegro is dominated by farms with a SO of less than 2,000 EUR. In North Macedonia and Serbia, the proportion is also quite high-between 46 and 50 percent. In all three countries, a small share of holdings have an SO above 8,000 EUR (Table 4). The EU also uses a market participation criterion for defining semi-subsistence farming, although this definition lacks specific thresholds for consumption and sales. Data on semi-subsistence farming based on market participation criterion are available only for North Macedonia (Table 4). Wharton (1969) proposed a cut-off point for differentiating semi-subsistence from commercial farming as 50 percent of output sold, a threshold which has been widely used in semi-subsistence farming studies including this one.

\section{TABLE 4: SHARE OF (SEMI-) SUBSISTENCE FARMERS IN SELECTED WB COUNTRIES, (\%)}

\begin{tabular}{|l|c|c|c|c|c|}
\hline & $\begin{array}{c}\text { Production for } \\
\text { self-consumption }\end{array}$ & $\begin{array}{c}\text { UAA }<\text { 0.5 } \\
\text { (subsistence) }\end{array}$ & $\begin{array}{c}\text { UAA }<2 \text { ha } \\
\text { (semi-subsistence) }\end{array}$ & $\begin{array}{c}\text { SO }<2,000 \text { EUR } \\
\text { (subsistence) }\end{array}$ & $\begin{array}{c}\text { SO }<\text {,000 EUR } \\
\text { (subsistence \& } \\
\text { semi-subsistence) }\end{array}$ \\
\hline Kosovo (2014) & 23.17 & 40.27 & 49.59 & 85.77 \\
\hline North Macedonia (2013) & 54.64 & 39.10 & 48.02 & 65.02 & 95.07 \\
\hline Montenegro (2010) & 37.91 & 35.5 & 45.87 & 86.03 \\
\hline Serbia (2012) & 11.4 & 36.8 & \\
\hline
\end{tabular}

Source: Kosovo Agricultural Census (2014), FYR Macedonia Farms Structure Survey 2013-preliminary data, Montenegro Agricultural Census (2010), Serbia Agricultural Census (2012).

in influencing labor allocation, in particular in countries with a large share of employment in agriculture and few alternatives for low skilled labor.

\section{Growth potential}

\section{Opportunities}

\section{Shifting consumer demand and increased climate} change risks will further shape the transition process of the agri-food industry in the Western Balkans in the next decade. During the last two decades, privatization of stateowned agricultural land, cooperatives and manufacturing enterprises as well as the integration of input, product, cred- it and services markets into the global economy have been the dominant forces driving the transition process of the agri-food industry in the Western Balkans. While these forces will continue to shape the sector in the Western Balkans in the next decade within the framework of the countries' WTO and EU pre-accession processes, they will be further amplified by the increasing input supply and financial risks posed by accelerating climate change as well as the shifting consumer demand in high-value export markets towards safe, healthy, convenient and sustainably grown origin products. In this regard, the sector will also need to respond to the new sustainability commitments undertaken by governments, businesses, and investors in the context of the recently adopted Sustainable Development Goals (SDGs) and

32 Fritzsch, J., S. Wegener, G. Buchenrieder, J. Curtiss and S. Gomez y Paloma (2010). Economic Prospects for Semi-subsistence Farm Households in EU New Member States. JRC Scientific and Technical Reports (EUR collection). Luxembourg.

33 Lerman, Z. (2004). Policies and institutions for commercialization of subsistence farms in transition countries, Journal of Asian Economies, Vol. 15, pp. 461-479.

34 Davidova, S., Bailey, A., Dwyer, J., Erjavec, E., Gorton, M. and Thomson, K. (2013). Semi-subsistence farming - value and directions of development. Study prepared for the European Parliament Committee on Agriculture and Rural Development, Brussels. 
the Paris Climate Accord. These combined market, environmental and regulatory forces point to a future of continued transformational change for the agri-food industry in the WB region, which will affect stakeholders across the agrifood value chain and beyond.

\section{Consumers in high-value export markets are shift-} ing their food and beverage expenditures towards safe, healthy, convenient and sustainably grown origin products. Whereas price and taste remain the most important factors determining food choices in high-value export markets in the EU, the purchases of consumers with higher disposable incomes are increasingly driven by other factors and values such as food safety, expected health benefits, sustainability and product origin. In the EU, this shift is largely the result of increased consumer awareness and information following recent food safety crises (e.g. e-coli, bovine spongiform encephalopathy, listeria and bird flu), which reduced consumers' trust in the agri-food industry and led to growing consumer interest in food production systems, processing practices, supply chain traceability and product origin. Meanwhile, the growing share of urban and elderly consumers in Europe continues to seek convenience in food and beverage products. However, they also demand that these products are healthy and «functional», i.e. convenience foods that are natural, minimally processed and provide personalized health benefits beyond basic nutrition. This includes organic products, whose consumption has grown very fast despite the recent financial crisis (European Commission, 2016 ${ }^{35}$ ).

\section{The modern retail sector is increasingly differentiating} products in response to shifting consumer demand and stricter regulations. As consumer demand in high-value export markets in Europe shift towards safe, healthy, convenient and sustainably grown origin products, modern food products are expected to become more differentiated in order to meet individual consumer preferences. In addition, a stronger focus is placed on niche markets and targeted products with a shorter product life cycle (European Commission, 2016). Although this trend tends to benefit large food and beverage manufacturers with multiple product supply chains, it also creates space for smaller, 'single play' food and beverage manufacturers, buyers and retailers to enter the market, especially when leveraging e-commerce platforms (Box 4). Regardless of their size and business model, increased flexibility, integration and coordination between producers, manufacturers, buyers and retailers are required to accommodate individual consumer needs. The need for close coordination across the agri-food value chain is further reinforced by the steady introduction of stringent public standards and regulations governing agri-food markets in the EU. In response to consumer/citizen demands, the EU has complemented its General Food Law (2002) with regulations focused on food hygiene (HACCP), food information and traceability. ${ }^{36}$ The EU has also expanded environmental regulations in regards to waste management, packaging and renewable energy.

37. The agri-food industry in the Western Balkans has experienced positive growth in recent years thanks in part to its gradual integration to regional markets. The agri-food industry in the Western Balkans experienced an estimated average annual growth rate of 11.9 percent in the period 2006 2011 compared to the EU average of 4.4 percent. ${ }^{37}$ The industry's positive growth rate has been underpinned by a strong regional export performance, which has been enabled by the gradual liberalization of regional custom tariffs. ${ }^{38}$ Overall, the WB economies' average applied tariffs for agricultural and industrial products are now largely in line with EU levels. ${ }^{39}$ With an average annual growth rate of 9 percent between 2006 and 2012, regional exports of food, beverages and tobacco

35 European Commission. 2016. The Competitive Position of the European Food and Drink Industry - Final Report, Directorate-General for Internal Market, Industry, Entrepreneurship and SMEs, Publications Office of the European Union, Luxembourg.

36 Regulation (EC) 852/2004 establishes general rules for hygiene of food stuffs; Regulation (EC) 1169/2011 introduces a minimum font size and rules on nutrition labelling. It also includes mandatory labelling of the country of origin or place of provenance for certain pre-packed fresh meat; Regulation (EC) No 178/2002 establishes basic traceability requirements. It requires food business operators to be able to identify from whom and to whom a product has been supplied ("one step back-one step forward traceability"), but they do not have to identify the immediate customers when they are final consumers. In addition, they are required to have systems and procedures in place that allow for this information to be made available to the competent authorities, upon request. Although the Regulation does not compel food/feed business operators to establish so-called internal traceability systems, a recent SME-focused survey by the European Commission indicated that around 75 percent of the respondents have an internal traceability system.

37 No UNIDO data is available for Montenegro and Kosovo.

38 WB countries have pursued custom tariff liberalization in the framework of the CEFTA agreements with the countries in the region, the Stabilization and Association Process (SAP) with the EU, the multilateral agreements within the WTO, and bilateral agreements, in particular with EFTA, Turkey, and the Russian Federation. In the context of CEFTA, WB countries have fully removed tariffs for manufactured and agricultural products. In the context of their Stabilisation and Association Agreements with the EU, WB candidate and potential candidate countries have obtained duty-free exports for almost all products (with the exception of baby beef, wine and sugar) while gradually reducing tariffs on imports form the EU.

39 OECD. 2016. Competitiveness in South East Europe: A Policy Outlook, Competitiveness and Private Sector Development, OECD Publishing, Paris, p88. 


\section{BOX 4. E-COMMERCE GROWTH IN THE FOOD INDUSTRY IN SPAIN}

In Spain, 3 precent of Spaniards shop online, but of those that use the Internet to purchase food, 60 percent shop fairly often (about nine purchases a year) according to a Capraboacasa.com survey done in collaboration with the Center for Demographic Studies in Catalonia. Even though the percentage of sales over total e-commerce sales is still low, the industry is growing stronger and firms are offering companies and consumers options to shop online at supermarkets, gourmet food stores and specialty shops. Since 2001, nearly all of the country's major supermarket chains offer online shopping through their websites, including Carrefour, Mercadona, El Corte Inglés and Erokski. Delinostrum.com is a gourmet food store created in 2005 that sells gourmet products from Spain to consumers throughout Europe. It offers a broad catalog of products and can customize gifts and deliver them anywhere in Europe. Highly specialized stores that focus on one kind of product are another trend in the industry. For example, Olivaoliva.com is an extra virgin olive oil marketplace that buys directly from olive oil mills in 16 Spanish provinces, often bottled right at the mill and delivered right to consumers' homes. Finally, there are multi-product platforms that don't use intermediaries but that sell products from different industries on a single platform. Examples of this type of platform are Mumumio, which offers organic vegetables, meats, beverages, fruit baskets, etc. and Directodelcampo.com, a Grupo Intercom business that offers a wide range of agri-food products.

Source: Nicolas, I.R. (2012). E-Commerce Growth in the Food Industry in Spain. E-Market Services, Spain. Available at http://www.emarketservices.com/clubs/ems/prod/E-Business \%20lssue \%20-eCommerce $\% 20$ growth $\% 20$ in $\% 20$ the $\% 20 f o$ od $\% 20$ industry $\% 20$ in $\% 20$ Spain.pdf

have grown rapidly compared to other manufacturing sectors in the region. ${ }^{40}$ Exports of food and beverages from the region have also grown faster than total world exports in the sector for key subsectors, including beverages, fruit and vegetables, dairy and edible oils, which has led to increased market shares (see Figure 9). Moreover, considering that a majority share of agri-food exports from WB countries currently consists of processed food and beverage products, the region's agri-food sector appears to be integrated into the final stages of agrifood value chains (see Figure 10).

\section{FIGURE 9. EXPORTS OF FOOD AND BEVERAGES FROM WB COUNTRIES HAVE GROWN FASTER THAN TOTAL WORLD EXPORTS, 2006-2012}

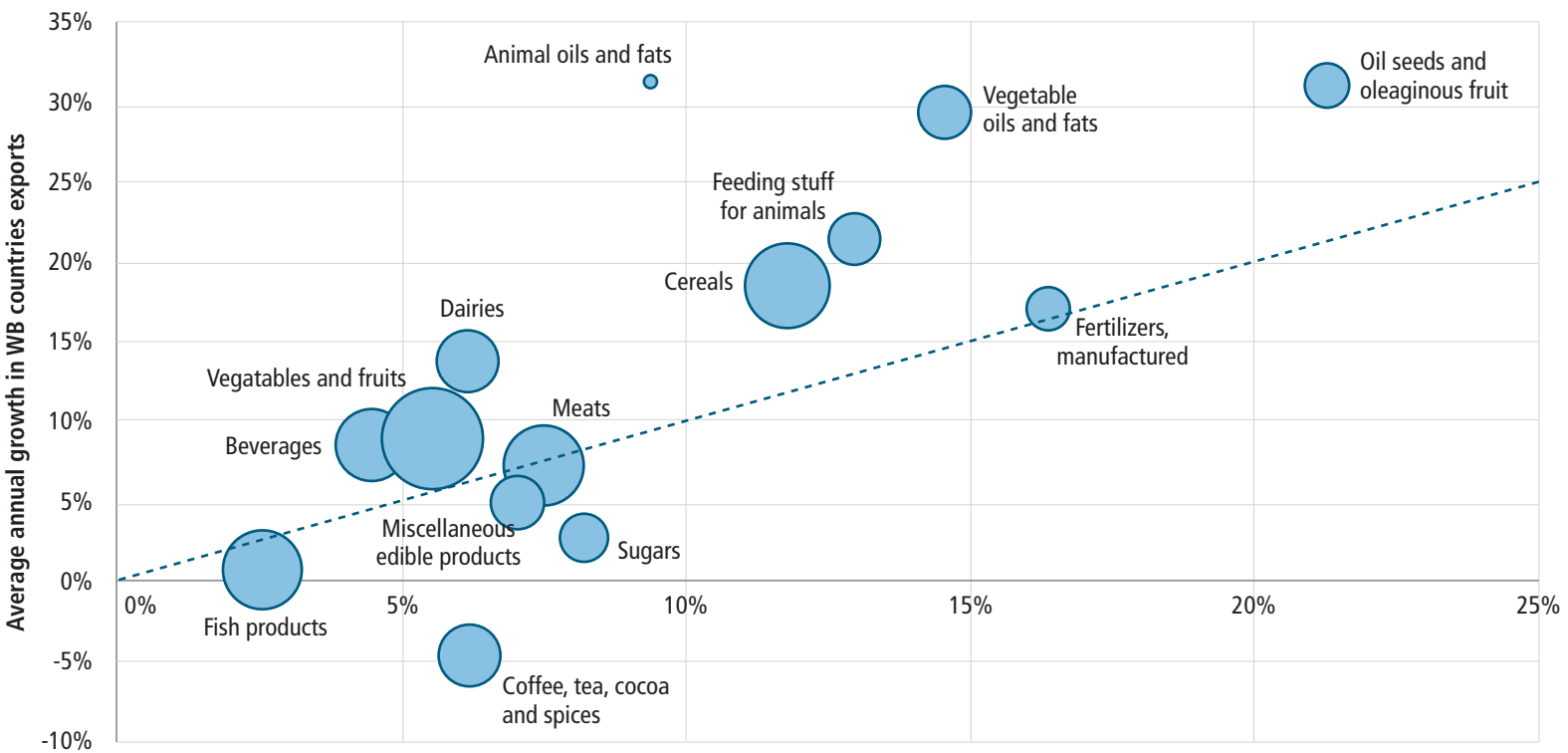

Average annual growth in world exports

Source: OECD.

Note: The size of the bubbles represents the size of the sectors as measured by total world exports in 2012 .

40 OECD. 2014. The Food and Beverages Processing Sector in South East Europe: Identification of Policy Constraints to Growth. Discussion Note available at: http://www.oecd.org/investmentcompact/Discussion\%20Note\%20-\%20First\%20Meeting\%20of\%20the\%20Food\%20and\%20Beverages\%20

Processing\%20Expert\%20Group.pdf 


\section{FIGURE 10. VALUE ADDITION IN AGRI-FOOD EXPORTS IS SIGNIFICANT, 2011}

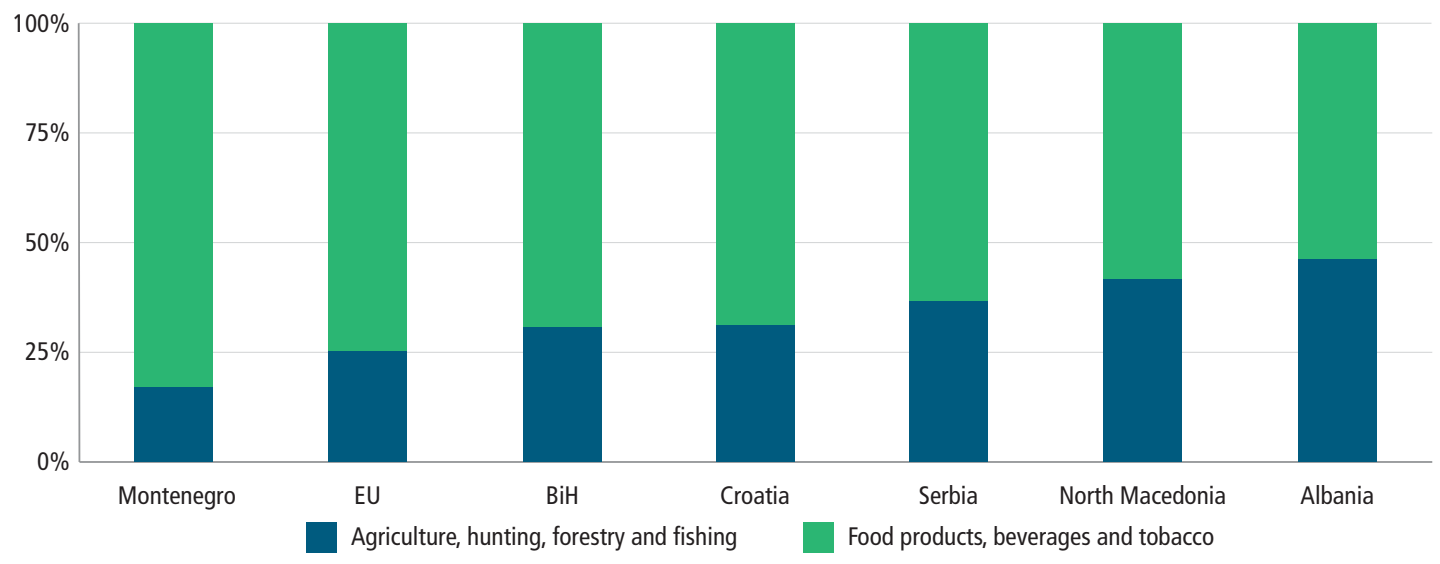

Source: OECD

Note: No data available for Kosovo.

38. WB countries have the potential to transform their agri-food industries into an engine of growth and decent jobs in this rapidly changing environment. WB countries are well-positioned to seize upon the growth opportunities created by shifting consumer demand in high-value export markets where agribusinesses tend to compete not only on price and cost, but also, and increasingly, on product quality and variety. The WB region has abundant land and water resources, including highly productive lands as well as large areas of less intensively cultivated and unpolluted land. Moreover, the region has diverse landscapes and favorable climate and soil conditions for producing a variety of high-value agri-food products such as fruits and vegetables, wine, spirits, meat, edible oils and dairy. Furthermore, WB countries benefit from competitive unit labor costs, a relatively educated workforce, a diversified industrial sector and reasonably developed infrastructure. Lastly, they enjoy geographic proximity to the EU and nearly unrestricted access to its markets. As a result, WB countries have the necessary productive assets and market opportunities to transform their agri-food industries into competitive providers of a diverse offering of high-value agri-food products.

\section{Growth in the agri-food sector is important in the con-} text of job creation and absorption. Agri-food businesses can help stimulate competitiveness in the rural economy as a whole and support the modernization process of the sector (Swinnen and Ciaian, 2008 ${ }^{41}$ ). In the new member states of the EU, previously in similar situations to the Western Balkans, foreign direct investment (FDI) in the agri-food industry was the most prominent contribution to productivity growth, quality improvements and enhanced competitiveness in the agricultural sector. Farmers have benefited greatly through vertical spillover effects and the general inflow of FDI into the agri-food sector which conditioned the restructuring of the agricultural supply chain (Swinnen and Van Herck, 200942). Vertical coordination in the industry can have important benefits for the food chain in terms of stimulating productivity.

39. Investments in agricultural competitiveness are closely related to employment and have strong multiplier effects. A recent analysis of World Bank investments in agricultural competitiveness finds that such industry competitiveness projects in agriculture show a positive correlation with the levels of employment. Investments in competitiveness generally focus on enhancing the business environment of agriculture through increasing the adoption of new and improved inputs and technologies, enhancing the capacity of agricultural institutions and improving agricultural infrastructure (e.g. improve links between agricultural producers and markets, reduce market transaction costs, align production decisions with business and market opportunities, link smallholder farms to international market supply chains). The analysis finds that agribusiness has the highest short-term indirect employment impact, where

41 Swinnen, J. and Ciaian, P. (2008). Growth, competitiveness and convergence in Romanian agriculture. Agricultural Economics and Rural Development, 5(3-4), 143-160.

42 Swinnen, J. and Van Herck, K. (2009). Agricultural Aspects of Accession to the European Union: Lessons from the EU New Member States and implications for FYR Macedonia. 
creating one job generates more than double the number of jobs in the rest of the economy (depending on the country's income level). Agribusiness has the highest short-term indirect impact because of its strong link to labor-intensive agriculture. Therefore, an increase in output in agribusiness will have a high indirect effect, especially in agriculture. Effects are lower, but significant, in the long term: every six jobs in agribusiness create one indirect job in the rest of the economy. Low indirect long-term effects are also present in other industries, but agriculture remains the industry with the lowest indirect job creation effect. Employment changes in agriculture are mostly associated with a change in market size. A negative correlation between employment and productivity is found to be particularly strong in agriculture, because of the sector's low efficiency (IEG, 2017³).

\section{Challenges}

40. Structural challenges to the competitive position of the agri-food industry must be addressed to realize this potential. To seize the growth opportunities in high-value export markets and create decent jobs while managing increased climate change risks, the agri-food industry in the Western Balkans must further strengthen its competitive position in international markets. Today, this position is constrained by the persistence of non-tariff barriers to trade, insufficient quality inputs and excessive industry fragmentation. These structural barriers translate into an agri-food industry that is currently characterized by low productivity and limited value added. Governments in the Western Balkans could help the agri-food industry to overcome these barriers by developing an enabling business environment and investment climate that are conducive to industry compliance with international quality standards, well-functioning value chains, innovation and entrepreneurship, foreign direct investments and trade, as well as sector-specific human capital development. Given that agri-food industry growth alone will not be able to absorb all the surplus labor in rural areas, the success of these efforts will critically depend on the integration of modern agri-food value chains inside diversified and knowledge-based rural economies.

41. Large agri-food trade deficits indicate that important challenges remain to the overall competitive position of the agri-food industry. Most WB countries maintain significant deficits in their trade balances of processed food and beverages (Figure 11). The only exception is Serbia, which is the largest exporter of agri-food products in the Western Balkans. In 2011, it registered a processed food and beverages trade surplus of EUR 592.2 million. ${ }^{44}$

42. The limited amount of FDI in the WB agri-food sector is another constraint to competitiveness. The agri-food industry remains significantly underrepresented in FDIs compared to its share in total manufacturing turnover. Whereas the sector accounted for 28 percent of total manufacturing

FIGURE 11. TRADE DEFICITS OF PROCESSED FOOD AND BEVERAGES ARE LARGE FOR BIH, ALBANIA AND MONTENEGRO, 2013

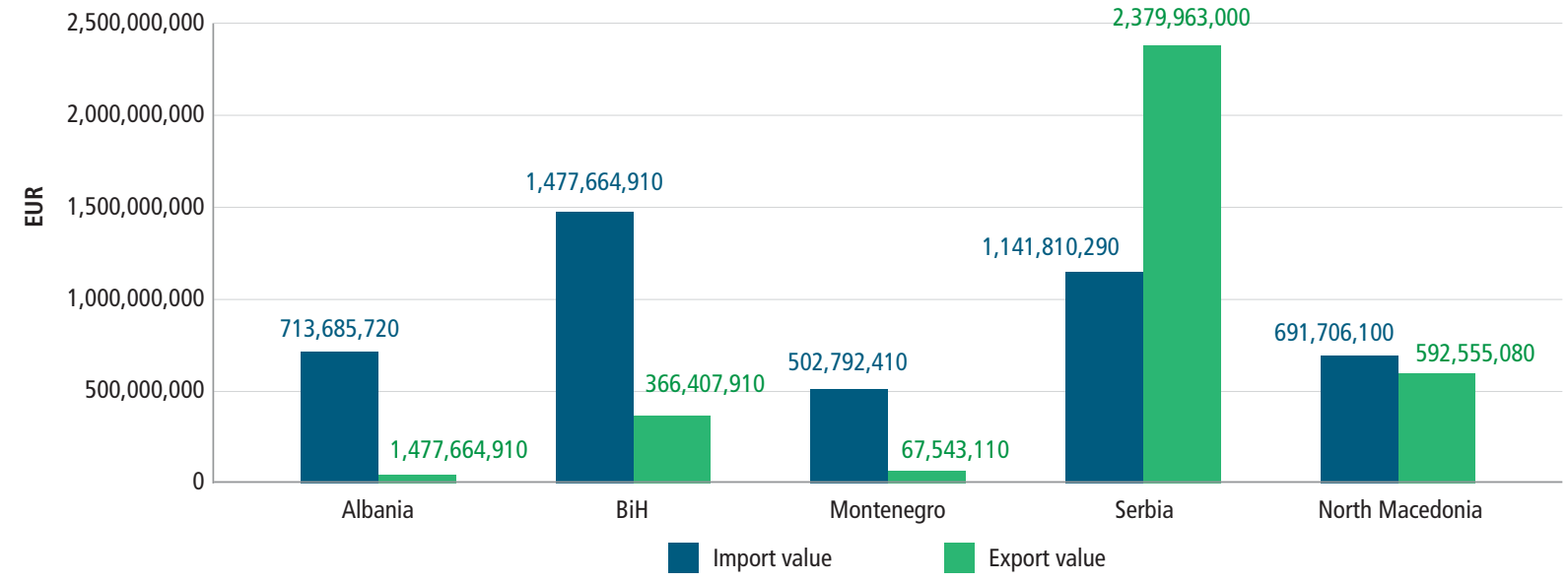

Source: FAO Eastern Europe and Central Asia Agro-Industry Development Country Briefs 2014.

Note: No data available for Kosovo.

43 Independent Evaluation Group (IEG). 2017. Industry Competitiveness and Jobs. An Evaluation of World Bank Group Industry-Specific Support to Promote Industry Competitiveness and its Implications for Jobs.

44 OECD. 2016. Competitiveness in South East Europe: A Policy Outlook, Competitiveness and Private Sector Development, OECD Publishing, Paris, p48. 
turnover in 2009, its share of total manufacturing FDI in 2010 was only 15 percent (see Figures 12.A and 12.B). In the three WB countries for which data are available, FDI in the agri-food industry (agriculture and food processing) follows different trajectories for the period 2008-2012. Albania experienced declining FDI inflows per capita, while $\mathrm{BiH}$, and in particular North Macedonia, managed to attract more FDI in the food industry (Table 5). In all three WB countries, FDI in the agricultural sector is relatively limited.

43. While trade logistics have generally improved in WB countries, agri-food manufacturers have mainly integrated in intra-regional value chains. With the exception of North Macedonia, WB countries improved their overall Logistics Performance Index between 2010 and 2014. ${ }^{45}$ Whereas their median performance rose from 2.66 in 2010 to 2.82 in 2014, the cost of importing and exporting one 20-foot container has dropped by 4 percent from 2012 to 2015. ${ }^{46}$ According to the World Bank's 2015 BEEPS survey, only 4 percent of companies across the region considered transport a significant barrier to business growth. However, the region's performance is still below the EU average. In 2014, global rankings ranged between 63 (Serbia) and 117 (North Macedonia). While trade logistics are improving, current trading patters suggest that food and beverage manufacturers in the Western Balkans are primarily integrating in intra-regional agri-food value chains and remain insufficiently connected to EU and global value chains. With the exception of Albanian manufacturers, who exported 20 percent of their agri-food exports (in terms of value) to Italy in 2013, food and beverage manufacturers in the WB region export mainly to other countries in the region. ${ }^{47}$

44. Various non-tariff barriers remain to accessing both EU and regional markets. Non-tariff barriers to trade may include technical regulations and product standards, sanitary and phytosanitary (SPS) measures, administrative barriers and import licenses. In the WB region, there remains significant room for removing SPS-related and, to a lesser extent, technical barriers to trade. Although key national legislation has been aligned with the EU's General Food Law, different adoption rates of EU SPS and technical regulations, divergent national interpretations, muddling of food safety and food quality non-conformities, and weak institutional capacity lead to varying compliance requirements and enforcement conditions in WB countries. ${ }^{48}$ Also, there is no systematic notification of new SPS and technical regulations, mandatory conformity assessment procedures,
FIGURE 12.A. ALTHOUGH FOOD AND BEVERAGES REPRESENT A LARGE SHARE OF MANUFACTURING TURNOVER (2009)...

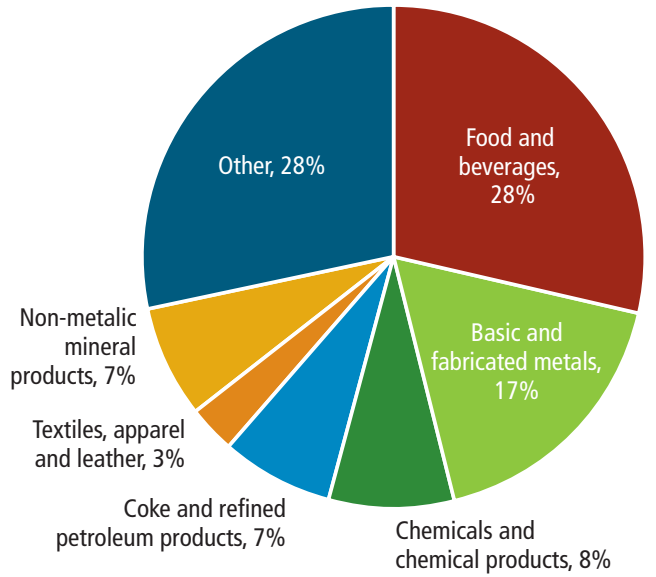

FIGURE 12.B. ...THE SHARE OF MANUFACTURING FDI THAT GOES TO FOOD AND BEVERAGES IS PROPORTIONATELY SMALL (2010)

Source: OECD

\footnotetext{
45 The World Bank's Logistics Performance Index (LPI) is a multi-dimensional international benchmarking tool for measuring countries' trade and transport facilitation friendliness. It analyses countries' performances against six areas of logistics-customs, infrastructure, ease of arranging shipments, quality of logistics services, tracking and tracing, and timeliness. They are measured on an ascending scale of 1 to 5 (very good).

46 OECD. 2016. Competitiveness in South East Europe: A Policy Outlook, Competitiveness and Private Sector Development, OECD Publishing, Paris, p224.

47 FAO Eastern Europe and Central Asia Agro-Industry Development Country Briefs 2014.

48 OECD (2016), Competitiveness in South East Europe: A Policy Outlook, Competitiveness and Private Sector Development, OECD Publishing, Paris, pp. $91-92$.
} 


\section{TABLE 5. FOREIGN DIRECT INVESTMENT IN THE FOOD SUPPLY CHAIN (INWARD STOCK), 2012}

\begin{tabular}{|l|c|c|c|c|c|}
\hline Country & $\begin{array}{c}\text { Agriculture } \\
\text { (million EUR) }\end{array}$ & $\begin{array}{c}\text { Food industry } \\
\text { (million EUR) }\end{array}$ & $\begin{array}{c}\text { Wholesale and retail } \\
\text { (mllion EUR) }\end{array}$ & $\begin{array}{c}\text { Agri-food industry } \\
\text { (EUR per capita) }\end{array}$ & $\begin{array}{c}\text { Wholesale and retail } \\
\text { (EUR per capita) }\end{array}$ \\
\hline Albania & 1.90 & 42.40 & 189.10 & 15.26 & 65.16 \\
\hline BiH & 24.50 & 372.90 & 677.70 & 103.51 & 176.52 \\
\hline North Macedonia & 36.50 & 261.10 & 453.90 & 144.48 & 220.36 \\
\hline Croatia & 147.60 & 536.50 & $2,290.20$ & 159.99 & 535.60 \\
\hline Czech Republic & 190.00 & $3,512.00$ & $11,071.00$ & 352.39 & $1,053.83$ \\
\hline Estonia & 398.80 & 404.90 & $1,827.50$ & 606.47 & $1,379.02$ \\
\hline Hungary & 465.20 & $1,853.90$ & $8,996.10$ & 233.50 & 905.78 \\
\hline Latvia & 294.50 & 190.80 & $1,351.20$ & 237.33 & 660.79 \\
\hline Lithuania & 112.90 & 318.70 & $1,415.40$ & 143.69 & 471.23 \\
\hline Poland & 662.00 & $10,654.00$ & $25,338.00$ & 297.29 & 665.67 \\
\hline Romania & $1,402.00$ & $2,153.00$ & $6,714.00$ & 176.90 & 334.10 \\
\hline Slovenia & 12.60 & 123.8 & $1,827.80$ & 66.36 & 889.23 \\
\hline
\end{tabular}

Source: WII database on FDI in Central, East and Southeast Europe (Hunya, 2014 and 2013).

and draft national standards. ${ }^{49}$ This negatively impacts the competitiveness of the agri-food industry by creating additional costs and uncertainty. In general, neither National Standards Bodies (NSBs) nor national SPS agencies have the capacity to actively and consistently participate in EU and international technical committees. ${ }^{50}$ In addition, food safety agencies in the region are understaffed and lack sufficient resources for inspectors' training and inspection equipment, as well as to perform regular testing to consistently enforce public food safety and quality standards. Although the relevant legal and regulatory frameworks are in place in all WB countries, risk management analysis is still not implemented in practice..$^{51}$

45. Lack of access to sufficiently large and reliable volumes of quality inputs further constrains the competitiveness of agri-food manufacturers in the Western Balkans. Local access to sufficient volumes of quality inputs is key to agrifood industry competitiveness. However, smaller producers, which dominate the production structure in the WB region, participate mainly in short-value chains that typically end at local green or wholesale markets. Food and beverage manufacturers in the Western Balkans therefore rely primarily on wholesale buyers, consolidators or large individual produc- ers when sourcing raw materials for processing. As contract farming is not widely used in the region, transactions remain largely ad hoc and contract breaches and delayed payments are frequent issues. In general, Albania (116), $\mathrm{BiH}$ (64), Serbia (61) and Montenegro (41) rank poorly on the World Bank Doing Business "Enforcing Contracts" indicator, which assesses the efficiency of the judicial system in resolving a commercial sale dispute. Current post-harvest operations in the Western Balkans further undermine product freshness and quality, while often providing products that are unsorted, of lower grade and unsuitably packed for transport. Most WB countries have limited and outdated cold storage capacities, which are often not adequately located for certain crops. Many existing buyout and distribution centers also lack the logistical arrangements as well as infrastructure design, technology, techniques and know-how to provide a full range of grading, sorting and packing services that meet buyers' quality and delivery requirements. ${ }^{52}$

\section{Fragmentation, low capital investment and weak R\&D} expenditures inhibit the productivity of the agri-food industry in the Western Balkans. The agri-food industry in both the Western Balkans and the EU is dominated by SMEs. In 2011, the average number of people employed by food

49 Although most CEFTA Parties have established enquiry and notification points and are publishing notifications of their legislation and measures on official websites, these enquiry and notification points are not always functioning properly and have capacity limitations.

50 For example, only North Macedonia's NSB is a member of CEN and CENELEC, while the others (apart from Kosovo's) are affiliates and have observer status in CEN and CENELEC technical committees according to national priorities.

51 OECD. 2016. Competitiveness in South East Europe: A Policy Outlook, Competitiveness and Private Sector Development, OECD Publishing, Paris, pp. 91-92. 52 AgBizMK (2014) Report: Survey to Assess and Prioritize Technical Needs in Leading Ag Sub-Sectors and Identify new Export Opportunities, USAID Regional Economic Growth (REG) project. 
and beverage manufacturers in most WB countries (16.6) was close to the EU average (14.6) (Figure 13). Only Serbia (21.5) and Albania (2.7) are notable exceptions. However, there are major gaps in terms of turnover between food and beverage manufacturers in the Western Balkans and the EU. The average regional turnover was less than 25 percent the EU average in 2011. Average turnover in Serbia (EUR 2.1 million), which is the highest among the WB countries, still represented less than half the EU average (Figure 14). Low turnover is in part driven by the fragmentation that characterizes the agri-food industry in several WB countries. While the average number of food and beverage manufacturers per million inhabitants in the Western Balkans (588) is close to the EU average (575), there are wide variations between countries in the region (Figure 15). For example, the number of agri-food manufacturers appears to be very low in $\mathrm{BiH}$ (219), whereas the numbers for Albania $(1,035)$ and North Macedonia (704) are significantly higher. In addition, agrifood industry productivity in the WB countries suffers from low capital investments and R\&D expenditures. Average gross fixed capital formation of food, beverage, and tobacco manufacturers in the Western Balkans amounts to only 22.2 percent of the EU average (Figure 16). Overall private sector $R \& D$ expenditures in North Macedonia accounted for only 0.02 percent of GDP in 2010 and 0.09 percent in Serbia, while the figure was 1.24 percent in the EU. ${ }^{53}$
47. Agribusinesses in the Western Balkans innovate despite insufficient private $R \& D$ investments. $A$ recent $O E C D$ survey of companies in the agri-food sector in $\mathrm{BiH}$ revealed that 86 percent had introduced some form of innovation in the previous three years. ${ }^{54}$ And according to the Innovation Union Scoreboard, North Macedonia and Serbia perform relatively well in business product, process, marketing and organizational innovations. ${ }^{55}$

FIGURE 13. THE FOOD, BEVERAGE AND TOBACCO MANUFACTURING ENTERPRISES EMPLOY A LARGE NUMBER OF PEOPLE, 2011

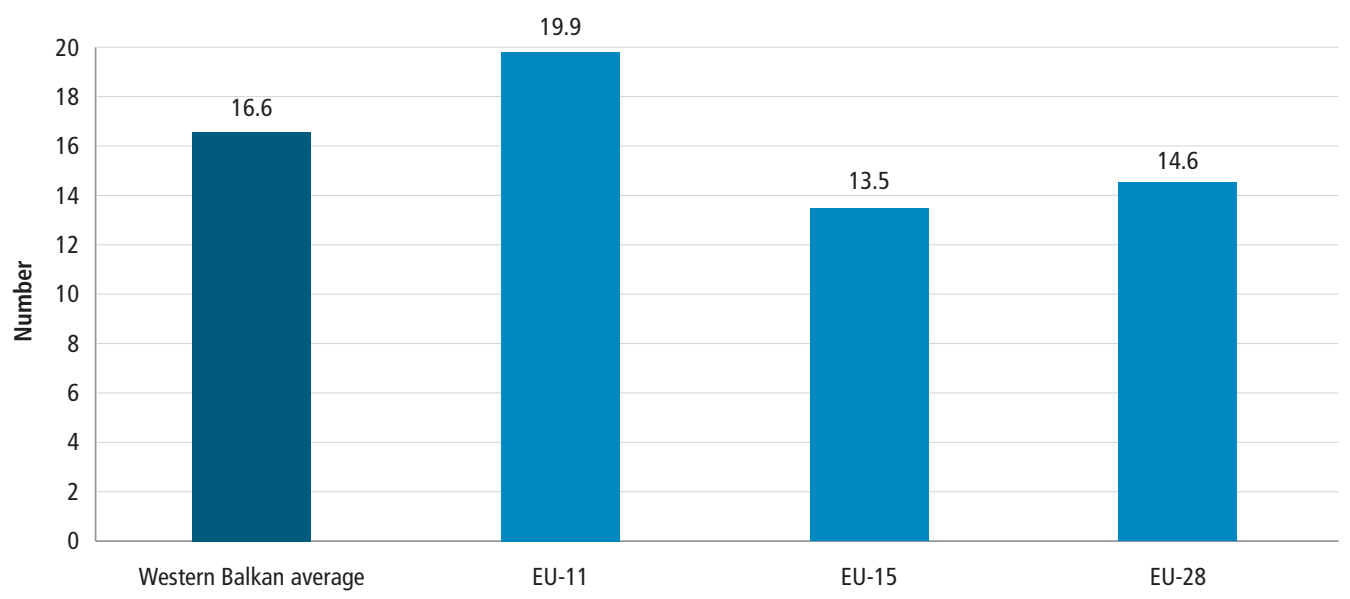

Source: UNIDO, FAO Eastern Europe and Central Asia Agro-Industry Development Country Briefs 2014.

Note: No data available for Kosovo.

53 OECD. 2016. Competitiveness in South East Europe: A Policy Outlook, Competitiveness and Private Sector Development, OECD Publishing, Paris, p137. 54 OECD. 2016. Competitiveness in South East Europe: A Policy Outlook, Competitiveness and Private Sector Development, OECD Publishing, Paris, p137.

55 In North Macedonia, 39 percent of companies reported producing innovation, as did 36 percent in Serbia, compared to an average of 38 percent in the EU. Figures are broadly similar when it comes to marketing and organizational innovations -30 percent of firms have introduced them in North Macedonia and 39 percent in Serbia, compared with 40 percent on average in the EU. 
FIGURE 14. THE AVERAGE TURNOVER OF FOOD, BEVERAGE AND TOBACCO MANUFACTURING ENTERPRISES IS SMALL, 2011

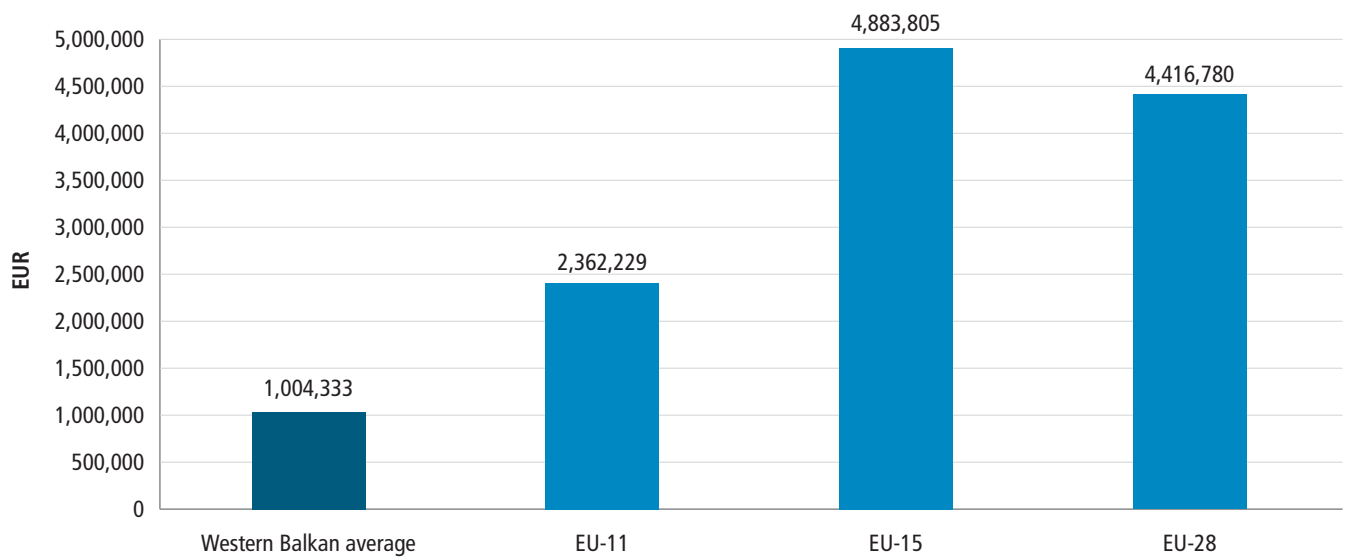

Source: FAO Eastern Europe and Central Asia Agro-Industry Development Country Briefs 2014 Note: No data available for Kosovo.

FIGURE 15. THE DENSITY OF FOOD, BEVERAGE AND TOBACCO MANUFACTURING ENTERPRISES (PER MILLION INHABITANTS) IS SIMILAR TO THE EU, 2011

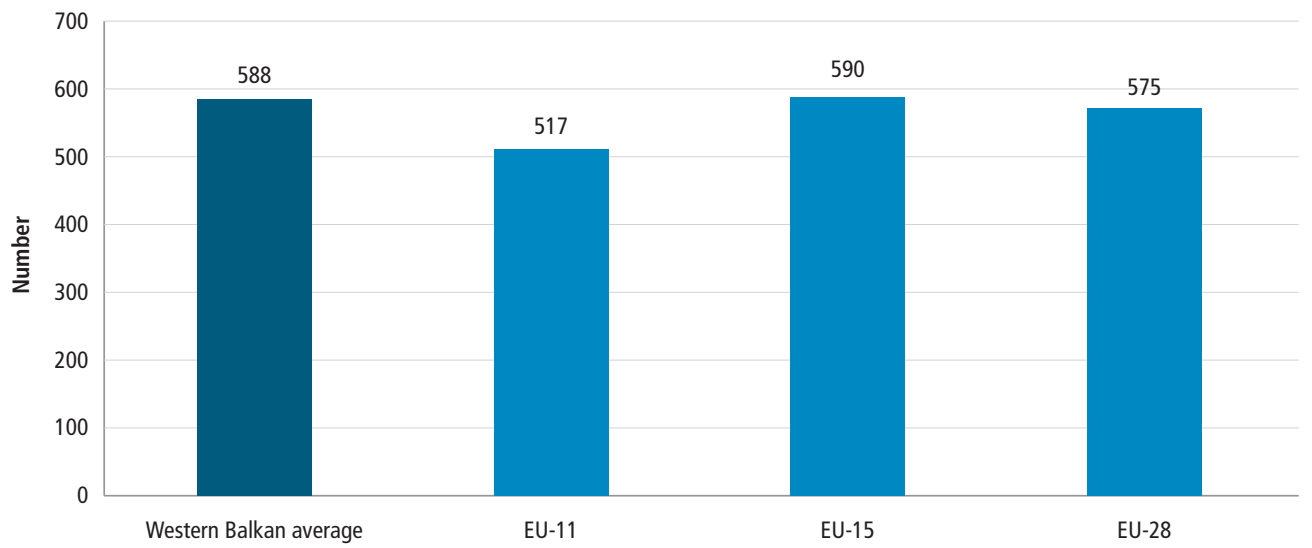

Source: FAO Eastern Europe and Central Asia Agro-Industry Development Country Briefs 2014.

Note: No data available for Kosovo.

FIGURE 16. THE AVERAGE GROSS FIXED CAPITAL FORMATION OF FOOD, BEVERAGE AND TOBACCO MANUFACTURING ENTERPRISES IS SMALL, 2011

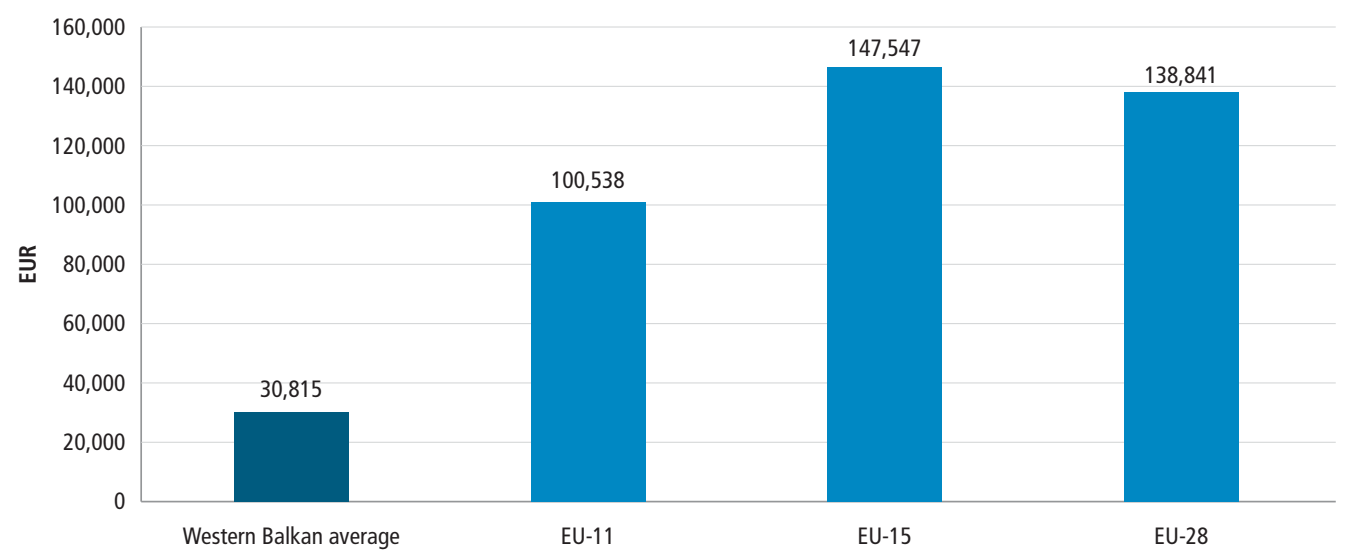

Source: UNIDO.

Note: No data available for Kosovo, Montenegro and Serbia. 
50. In terms of harmonization of specific policy instruments with the CAP, significant differences in the degree of the actual adjustment exist. Anecdotal evidence suggests that the proposed policy instruments are still predominantly an outcome of political and interest-motivated choices rather than being designed based on objective criteria (Bajramović et al., 2016 p.18). Serbia and Montenegro are well-advanced in this regard having actually put forward plans for the gradual introduction of CAP elements, while other Western Balkans have not yet designed a clear plan of harmonization with the CAP. ${ }^{59}$ With the CAP evolving, this could be an opportunity to develop plans that align with developing CAP considerations for modernization and simplification: (i) the CAP is a vehicle for addressing opportunities and challenges for climate and the environment; (ii) quantifying CAP's wider contribution on jobs and growth is difficult but needed; (iii) bottlenecks in the food chain provide opportunities to refocus some policy responses.

51. To simulate the economic impacts of policy support, an input-output analysis of the agri-food sector was carried out ${ }^{60}$ for two countries, for which data is available-Albania and North Macedonia. The scenarios are presented in detail Annex 1. The main findings suggest:

a) The economic impacts of the agri-food sector are significant in both countries and reflect the respective economic development contexts (see Table 6). In Albania, the agri-food industry is «responsible» (directly and indirectly) for almost half the econo- my-wide jobs, while in North Macedonia (where the economy has already embarked in a diversification process) it creates nearly a third of employment. The results also reflect the development level and structural characteristics of both economies from another point of view, i.e. this of sectoral interdependence (integration of sectors within the economy). In North Macedonia they reflect the higher (compared to Albania) links of agriculture with the rest of the economy, as indirect and induced effects linked to agri-food activity are higher.

b) A shift of policy towards rural diversification investment should be gradually but decisively attempted. This shift is a sine-qua-non condition following the successful implementation and positive results of investments in agri-food production and processing and in agricultural and rural infrastructure. This is because a more-diversified rural economy would facilitate the absorption of surplus farm labor and in parallel, contribute to the enhancement of economic linkages in rural areas and the reverse of rural decline.

c) The economic impacts of direct support to farmers (under Pillar 1) are not negligible, mainly due to the importance of agriculture in the two economies (see Table 7). In Albania, these impacts are constrained by the relatively low share of direct public support to farmers in total agricultural policy spending and also by the comparatively low links of farm activity with

\section{TABLE 6. ECONOMIC IMPACTS OF THE AGRI-FOOD SECTOR IN ALBANIA AND NORTH MACEDONIA}

\begin{tabular}{l|c|c|c|}
\hline Changes compared to $\mathbf{2 0 1 3}(\mathbf{\%})$ & Change in output & Change in value added & Change in employment \\
\hline ALBANIA & & $-23.91 \%$ & $-47.22 \%$ \\
\hline No agri-food sector & $-19.73 \%$ & $5.70 \%$ & $15.31 \%$ \\
\hline Double livestock production & $6.01 \%$ & $4.10 \%$ & $11.63 \%$ \\
\hline Double fruits \& vegetables production & $2.49 \%$ & & $-30.14 \%$ \\
\hline NORTH MACEDONIA & & $-18.15 \%$ & $6.25 \%$ \\
\hline No agri-food sector & $-19.06 \%$ & $2.75 \%$ & $3.12 \%$ \\
\hline Double livestock production & $2.40 \%$ & $1.73 \%$ & $1.94 \%$ \\
\hline Double fruits \& vegetables production & $1.15 \%$ & $0.87 \%$ & \\
\hline Double forage production & $0.72 \%$ & & \\
\hline
\end{tabular}

Source: Psaltopoulos, D. (2017)

59 These differences might reflect the different stage of their EU accession processes.

60 The analysis was carried out by Professor Demetris Psaltopoulos (University of Patras, Greece) as an input to this study. The full report on the inputoutput analysis can be provided upon request. It includes: 1) the main characteristics and elements of IO analysis; 2) other similar analyses performed at the EU level and their main findings; 3 ) the 10 model construction process and, in more detail, the subset of countries to which this method is applied, the 10 models elaboration process and its relevant assumptions; and 4) specification of policy scenarios and scenario analysis results. 
TABLE. 7. IMPACTS OF CAP ON EMPLOYMENT IN

ALBANIA AND NORTH MACEDONIA

\begin{tabular}{l|c|c|} 
& \multicolumn{2}{c}{ Change in employment } \\
\hline Support for policy & ALBANIA & $\begin{array}{c}\text { NORTH } \\
\text { MACEDONIA }\end{array}$ \\
\hline Pillar 1: Direct payments & $6 \%$ & $1 \%$ \\
\hline Pillar 2: Rural development programs & $13 \%$ & $-3 \%$ \\
\hline Pillar 2: Farm modernization & $10 \%$ & $1 \%$ \\
\hline Pillar 2: Food processing & $10 \%$ & $4 \%$ \\
\hline Pillar 2: Rural infrastructure & $-6 \%$ & $-2 \%$ \\
\hline Pillar 2: Rural income diversification & $-2 \%$ & $0 \%$ \\
\hline Re-orientation of support (IPARD) & $18 \%$ & $0 \%$ \\
\hline Sorce: Pstopols, D. (2017). & & \\
\hline
\end{tabular}

Source: Psaltopoulos, D. (2017)

the rest of the economy. In North Macedonia, higher economic linkages developed between farm activity and the rest of the economy lead to the generation of significant economic impacts of farm support (see Annex 1, Tables 1 and 2). In Albania, allocation of funds towards Pillar 2 can bring a 13 percent increase in employment, with farm modernization and food processing being important generators of employment due to their labor intensity. In North Macedonia, the impacts are much lower (in proportional terms), with funds allocated to food processing having the largest relative impact of 4 percent increase in employment.

d) Strengthening of economic interdependence in the food chain is critical for job creation and growth. Support for investment measures which result into demand for the output of sectors characterized by low economic linkages (e.g. trade sector in Albania, construction sector in North Macedonia) generates comparatively lower economic effects (and vice-versa). If economic linkages are already low within the food chain (e.g. Albania), doubling them does not result into significant effects for economy-wide output, incomes and jobs (and vice-versa). This particular finding indicates the importance of pursuing policy initiatives which would facilitate the strengthening of economic interdependence in the food chain and rural areas. For example, in North Macedonia, if the agri-food sector doubles its purchases of domestically-produced farm products, employment in the economy increases by 21 percent while also rising output and value added by 16 percent (see Table 8 ). e) An increase in support for agricultural modernization, food processing and rural infrastructure might not generate immediate substantial economic effects, but in the medium and longer terms, it would lead to an improvement in agri-food competitiveness, an increase of the currently low economic interdependence and, ultimately, a notable improvement in the economy-wide growth and jobs. Within this context, an especially important issue relates to the increase of links between agriculture and food processing, for which there is certainly much room for improvement, especially in Albania. Taking into account the employment and growth generating capacity of the food sector, and the significant needs for its modernization in both countries (which in turn are linked with the modernization needs of primary production), emphasis should be given to the exploitation of its economic potential.

52. To move from policy to economic impact, a number of areas can and should be addressed to improve the performance of the sector by creating an enabling environment for investment and job creation:

\section{a) Promoting compliance with international quality standards}

53. Ensuring compliance with public and private food safety and quality standards is a precondition for entering high-value markets at home and abroad. As the retail sector becomes increasingly consolidated in the Western Balkans and the EU, compliance with both public and private food safety and quality standards becomes a de facto barrier for producers and manufacturers to enter high-value markets. Agri-food manufacturers in the Western Balkans are required to implement HACCP-based food safety and quality management systems. While other public and private food safety and quality standards are applied voluntarily, WB countries have nonetheless been promoting their implementation and certification. Besides HACCP, the most common certifications in the agri-food industry in the Western Balkans cover food safety (ISO 22000, IFS, GMP, BRC, FSMS), which are needed particularly for manufacturers that aim to supply supermarkets in the EU directly, food quality management (ISO 9000) and environmental management concerns (ISO 14001). ${ }^{61}$ In general, ISO certification rates increased across the Western Balkans between 2010 to 2013, but they have stagnated since. Across the WB

61 Djekic, I. et al. (2011). Quality and Food Safety Issues Revealed in Certified Food Companies in Three Western Balkans Countries, Food Control Journal Vol. 22, p1734. 


\section{TABLE 8. IMPACTS OF CHANGES IN THE MAGNITUDE OF DOMESTIC DEMAND}

\begin{tabular}{|c|c|c|c|}
\hline Impacts compared to no change in policy (2013) & Change in output & Change in value added & Change in employment \\
\hline \multicolumn{4}{|l|}{ ALBANIA } \\
\hline Double livestock links & $2 \%$ & $2 \%$ & $5 \%$ \\
\hline Double fruits \& vegetables links & $2 \%$ & $2 \%$ & $6 \%$ \\
\hline Double food chain links & $3 \%$ & $3 \%$ & $9 \%$ \\
\hline \multicolumn{4}{|l|}{ NORTH MACEDONIA } \\
\hline Double food chain links & $16 \%$ & $16 \%$ & $21 \%$ \\
\hline
\end{tabular}

Source: Psaltopoulos, D. (2017).

region, the number of ISO 9001 certificates registered per million inhabitants is lower than in the EU. Serbia has the highest rate, while Albania, North Macedonia and Montenegro have the lowest. ${ }^{62}$ Compliance with international food safety and quality standards requires comprehensive knowledge and internal capacity for companies to adopt, maintain and manage (e.g. through self-audits) on a day to day basis. In addition to the cost-efficient provision of public food safety and quality inspections services, agribusinesses require access to finance for equipment upgrades as well as local company technicians and external advisors to manage the different compliance requirements associated with international quality standards.

54. Sustainability standards and certifications could provide economic, social and environmental benefits for the agri-food industry in the Western Balkans. International sustainability standards and certification systems can strengthen the agri-food industry's competitiveness by enabling access to productive and resilient supply chains, enhancing business reputation, adding market value and reducing both the operational and compliance costs associated with environmental regulations..$^{63}$ In particular, organic certification can be a source for value addition and job creation in the broader agri-food sector (Box 5). The rapid rise in consumer demand for organic products in the EU so far outpaces supply considerably. As a result, excess demand in the EU is currently met through imports of organic products from third countries. ${ }^{64}$ The WB region is well-positioned to help bridge the current supply gaps in key EU export markets for organic products. Agriculture in the Western Balkans is less fertilizer-intensive than the EU average of $149 \mathrm{~kg}$ per hectare of arable land per year..$^{65}$ In addition, the region's smaller-scale farms and agribusinesses, in combination with competitive unit labor costs, lend themselves well for more labor-intensive organic production systems. Despite a number of policy measures supporting organic certification, the area of agricultural land used for organic farming remains limited: from 0.05 percent in $\mathrm{BiH}$ to 0.7 percent in Montenegro in 2009. However, with an average annual growth rate of 57 percent in the period 2005-2010 the development trend is extremely positive. ${ }^{66}$ The most significant organic produce common to almost all the countries of the region is that of small fruits (cherries, strawberries, raspberries, blueberries and blackberries), aromatic and medicinal herbs and certain types of cereals. ${ }^{67}$ In recent years, Montenegro has made headway in planning and implementing a range of agri-environmental support measures designed to strengthen sustainable agriculture, including incentives for organic agriculture. In addition, North Macedonia has started to prepare for implementing agri-environmental measures, but other WB countries are still to develop a framework to support agri-environmental policies. Albania and $\mathrm{BiH}$ have the greatest potential for improvement when it comes to sustainable agriculture.

\section{Specialty products and origin labels can further dif-} ferentiate product offerings in high-value export markets.

62 OECD. 2016. Competitiveness in South East Europe: A Policy Outlook, Competitiveness and Private Sector Development, OECD Publishing, Paris. 63 Molenaar, J.W. and Kessler, J.J. (2017). The Business Benefits of Using Sustainability Standards - A Meta Review, Aidenvironment, Amsterdam, p4. 64 For example, the number of registered importers of organic produce in the EU grew from less than 500 to more than 3,000 in the period $2009-2012$. 65 Fertilizer use lies between Montenegro's $12 \mathrm{~kg}$ (thanks to the extensive non-fertilizer-intensive wine industry) and $99 \mathrm{~kg}$ in BiH. The only exception is Serbia, which uses $175 \mathrm{~kg}$ per hectare of arable land per year.

66 Znaor, D. and Landau, S. (2014). Unlocking the Future: Sustainable Agriculture as a Path to Prosperity for the Western Balkans, Heinrich Böll Stiftung, Zagreb, p45.

67 Grozdanic, R. (2013). Agribusiness and Agro-Industrial Strategies, Policies and Priorities for Achieving Higher Competitiveness, Employability and Sustainability in the Western Balkans Region, Friedrich Ebert Stiftung and European Federation of Food, Agriculture and Tourism Trade Union (EFFAT), Belgrade, p65. 


\section{BOX 5. ORGANIC FARMING BENEFITS AND COSTS}

Positive impacts of organic farming on the environment and climate resiliency are evident in the form of improved soil quality, ecosystem services, as well as ground and surface water. According to recent studies, organic farming has also demonstrated that it can yield more total food produce than conventional farming on the same amount of land. In addition, consumers pay a premium for organic food compared to conventional products as education, expected health benefits and greater availability positively influence consumer attitudes towards buying organic food. Organic farming also benefits the economy in terms of greater employment and business diversification. Organic farms are more labor intensive than industrials ones and create additional higher-skilled jobs downstream agri-food chains and beyond. This includes employment opportunities in post-harvest operations and processing (e.g. quality sorting, special handling, and storage), production of organic agricultural equipment and green inputs (e.g. natural fertilizers), transportation and logistics, agroecological research and extension and third party audit and certification.

A comprehensive field survey of organic farming in the UK and Ireland found higher labor intensity per organic farm (i.e. 97 percent and 27 percent respectively) relative to conventional farms. The UK Soil Association analyzed the survey data and found that, on a weighted basis, organic farms averaged 32 percent higher labor requirements than comparable non-organic farms. On-farm employment gains included, in particular, casual and employed part-time labor inputs.

Despite frequent yield decreases in the early years of organic implementation, organic farms are more economically profitable due to the reduction of production input costs, increased variety of total farm products and organic premium market prices. The main drivers underpinning the social and environmental benefits of organic and sustainable farming practices include the increased manual and mechanized labor inputs for more diverse cropping rotations; integration of crops and livestock in order to recycle organic wastes into soil nutrients; maintenance of crop residue and 'green manure' ground covers to reduce soil erosion; greater reliance on biological processes for pest and weed management; and many other agroecological farming methods. Significant investments are needed to make the transition from both the industrial farming practices of the developed world and from the more traditional, low productivity practices common in the developing world to more sustainable food production systems. Organic certification and inspection costs generally represent between 2 and 10 percent of the total costs of organic products in well managed operations, but there are cases where these costs have been as high as more than half of total costs. Studies therefore indicate the importance of certifying at the right scale, in particular through group and participatory certification processes, in order to effectively manage certification costs and reduce the risk of excluding smaller producers.

Source: FAO (2012). Green Jobs for a Revitalized Food and Agriculture Sector, Natural Resources Management and Environment Department, Rome, p10-p12.

In light of the individualization trend in consumer demand and the accompanying focus on more niche and targeted products, specialty products and origin labels such as Geographical Indications (GIs) have strong growth potential and provide an additional avenue to differentiate products in high-value export markets in the EU. A recent EU study showed that 10 from the $13 \mathrm{Gl}$-products analyzed obtained a price premium compared to the corresponding standard good, but the price difference was less clear for producers who supply raw (versus processed) agricultural products. ${ }^{68}$ The EU instruments governing GIs require collective action by producers for the registration and implementation of Gls. GIs thus allow organized local producers to collectively define and manage production and processing quality standards, defend their products' reputation and communicate their value to consumers. They also help agri-food manu- facturers exploit the diversity and manage the fragmentation that characterizes the agri-food sector in the Western Balkans. International experience shows that success critically depends on strong collective action and self-organization by producers, clear geographical and social boundaries, shared knowledge and awareness on Gl processes, supportive national legislation, close coordination between all supply chain stakeholders (i.e. producers, manufacturers, government institutions and donors), implementation of credible certification and control systems, use of protected trademarks, as well as information and promotion campaigns to consumers. WB countries have extensive experience in regards to Gls (example in Box 6). So far, however, the socio-economic impact of GIs in the WB region has been limited mainly due to weak producer organizations and internal monitoring and control systems.

68 Areté (2013). Study on Assessing the Added Value of PDO/PGI Products - Executive Summary. Commissioned Study by the European Commission. Available at: http://ec.europa.eu/agriculture/external-studies/added-value-pdo-pgi_en.htm 


\section{BOX 6. FUTOG CABBAGE}

The Futog cabbage has become the first Serbian product to have a geographic certification mark. Producers achieved this certification, including previous successes related to preserving production, quality and building reputation, by effectively associating. The organization of producers and manufacturers of the Futog cabbage has benefited from project support from state institutions as well as donor agencies. Nevertheless, unlike others, this association has not only survived, but has continuously developed thanks to persistent and visionary management, continuous spreading of partnerships, and knowledge promotion. After five years, about 50 producers and 6 manufacturers of the Futog cabbage succeeded in getting a higher price for their product with a geographic certification mark (20 percent compared to the hybrid). Through joint marketing, the association has created a network of support for its "brand". At the same time, it acts as a guarantee and coordinator of the process of quality control with a view to preserve and promote the reputation of the product and thus the trust of the consumers.

Source: Zivkov, G. (2013) Association of Farmers in the Western Balkan Countries, Policy Studies on Rural Transition No. 2013-1, FAO Regional Office for Europe and Central Asia, Budapest, p27.

\section{b) Facilitating well-functioning agri-food value chains}

\section{Commercial partnerships can forge close value chain} coordination and align input supplies with markets' demands. Well-functioning value chains help the agri-food sector to better create, deliver and capture market value by closely coordinating actions between upstream and downstream agri-food value chain stakeholders. Manufacturers' ability to deliver standardized food and beverage products to consumers often depends on large scale changes in producers' production (e.g. seed use, rootstock production, varietal structure, natural resource management, etc.), processing, as well as marketing technologies and practices. Implementing such improvements requires long-term and comprehensive investments, technical assistance and coordination of public and private value chain stakeholders. Commercial partnerships, such as the "productive alliances" introduced by the World Bank in Latin America, Africa and East Asia since the 2000s, have demonstrated to be effective platforms for coordinating these types of actions across the value chain. ${ }^{69}$ Evidence from surveys and evaluations has shown that partnerships led to increases in production volumes, productivity, access to improved inputs and productive equipment, as well as producers' integration into new markets. Producers also benefited from better product quality and diversification, which increased sales volumes and prices. While some partnership programs led to improvements in employment and the generation of new jobs, the evidence is based on relatively small samples and varies strongly across value chains. ${ }^{70}$

57. Commercial partnerships in fragmented agri-food value chains critically depend on strong producer organization. Modern producer cooperatives are organized around a clear purpose, a well-defined market position, professional and market-oriented service delivery to members, as well as democratic controls by cooperative members over management and decision-making. Modern producer cooperatives strengthen smaller producers' position in agri-food value chains by facilitating joint procurement and supply of inputs, enabling access to finance and cost-sharing of investments, sharing best practices and increasing bargaining power with manufacturers, retailers, and traders. In addition, they raise productivity levels by upholding production quality standards, consolidating production outputs, conducting primary processing and joint marketing final products. Producer associations, for their part, enable smaller producers to participate and weigh into public policymaking processes that affect value chain development. They can also improve smaller producers' business management capacity by providing professional assistance and support. In general, various legal and institutional obstacles continue to hinder

69 Productive Alliances usually involve a group of commercially-oriented small producers, one or more large buyers and the public sector. They coordinate their activities on the basis of a "business plan" which outlines the investment, technical assistance and business development needs of the producers to upgrade and strengthen their linkage with the buyer(s). Business plans are implemented through sub-projects financed by public grants on the basis of transparent and technical selection criteria and matched by the beneficiary producers and in some cases also by the buyer(s).

70 World Bank. 2016. Linking Farmers to Markets through Productive Alliances: An Assessment of the World Bank Experience in Latin America, World Bank, Washington, D.C., pp. 1-4. 
the development of modern producer organizations in the Western Balkans. ${ }^{71}$ Although there are no clear regional statistics, survey data for Serbia and BiH suggest that the structure of agricultural cooperatives in the Western Balkans is dominated by micro-cooperatives and that there is great variation in their type and level of development. ${ }^{72}$ Despite the progress made in recent years, the number of modern cooperatives, including specialized cooperatives that are involved in some form of treatment or processing, remains small and their overall economic significance is limited. ${ }^{73}$ Although there is a great variety of producer associations in the Western Balkans, including associations representing specific (group) interests as well as inter-branch associations representing the interests of all the stakeholders in a given value chain, many cease to exist shortly after being established as a result of overly ambitious goals, poorly defined roles, or political interferences.

\section{Agri-food industry clusters could strengthen sector competitiveness by linking key support services to agri- food value chains. Well-functioning agri-food value chains depend on the provision of quality agribusiness support services, including physical input supplies (e.g. seeds or packaging materials), technical services (e.g. field spray- ing, storage, transport, laboratory testing, management training, market research and processing) and financial services. In fact, business support service providers (which can be private, public or civil society actors) play a crit- ical role in facilitating value adding processes as well as}

efficient transactions and products flows in agri-food value chains. Industrial clusters, which are geographic concentrations of businesses, business support service providers and associated institutions working in a related value chain (Figure 17), can help increase value chains' productivity, efficiency and innovation by virtue of location-specific externalities and synergies. These include specialized input suppliers and skills, enhanced competition, knowledge spillovers, cross-sectoral linkages, more cost-efficient delivery of public goods and better coordination and information flows between public and private sectors both inside and outside the value chain. ${ }^{74}$ While industrial clusters often evolve spontaneously over decades, well-designed cluster initiatives involving public-private dialogues at all levels of government can accelerate the process and catalyze complementary development. Several WB countries have developed cluster initiatives, including Serbia, North Macedonia (wine, lamb and cheese clusters), and Albania (meat processing, herbs and spices). ${ }^{75}$ However, recent research suggests that while cluster members in Serbia and North Macedonia recognize the benefits from improved access to information, business partners and supporting institutions, they reportedly have not gained better access to suppliers, skilled labor or financial institutions. ${ }^{76}$ Furthermore, all WB countries have set up special economic zones (SEZs), science and technology parks and other similar concepts. However, the administrative capacity to implement these incentives credibly and consistently is often weak.

71 Cooperative legislation in the Western Balkans constrains the development of modern cooperatives by laying out overly complex, detailed and prescriptive rules as opposed to regulating the formation and functioning of cooperatives. In addition, cooperative assets are usually considered common property and legislation does not distinguish profits derived from mutual trade from profits derived from cooperative assets. This prevents cooperative members from investing different amounts in acquiring assets and distributing profits accordingly. Furthermore, tax systems often do not differentiate between agricultural cooperatives and other agribusinesses, which renders cooperative members subject to double taxation. Producers in the Western Balkans therefore tend not to invest in producer cooperatives, but opt for the establishment of limited liability companies instead. Moreover, legal trade through cooperatives is also discouraged by the absence of VAT payments at the level of green and wholesale markets, which misdirects agricultural production, in particular fruit and vegetables, towards the informal sector. Finally, governments generally do not provide stable support programs to promote and incentivize investments in producer groups. See Zivkov, G. (2013) Association of Farmers in the Western Balkan Countries, Policy Studies on Rural Transition No. 2013-1, FAO Regional Office for Europe and Central Asia, Budapest, 35pp.

72 Older cooperatives are usually administered by employees (as opposed to farmers) and they are primarily focused on managing cooperative assets instead of market development. Most cooperatives in the Western Balkans operate in a manner similar to private businesses. They provide services to farmers, but they do not include them in decision-making processes opting for sub-contracts instead. A survey conducted by the Ministry of Agriculture of Serbia in 2010 showed that agricultural cooperatives have 4 to 5 times more contract farmers than cooperative members. Moreover, since these "private" cooperatives mainly focus on consolidating cereal and industrial crop production outputs for manufacturers, they often lack assets, which prevents them from offering credit instruments. See Zivkov, G. (2013) Association of Farmers in the Western Balkan Countries, Policy Studies on Rural Transition No. 2013-1, FAO Regional Office for Europe and Central Asia, Budapest, 35pp.

73 Zivkov, G. (2013). Association of Farmers in the Western Balkan Countries, Policy Studies on Rural Transition No. 2013-1, FAO Regional Office for Europe and Central Asia, Budapest, p20.

74 World Bank. 2009. Clusters for Competitiveness - A Practical Guide \& Policy Implications for Developing Cluster Initiatives, International Trade Department, PREM, World Bank, Washington D.C., p1.

75 Grozdanic, R. (2013). Agribusiness and Agro-Industrial Strategies, Policies and Priorities for Achieving Higher Competitiveness, Employability and Sustainability in the Western Balkans Region, Friedrich Ebert Stiftung and European Federation of Food, Agriculture and Tourism Trade Union (EFFAT), Belgrade, p30.

76 VII Balkan and Black Sea Conference. 2016. Days of Clusters 2016: Creating Cluster-based Economic Development for a Sustainable Region, $22-24$ September, Ohrid, North Macedonia, Conference proceedings available at: https://blacksea-horizon.eu/object/document/696/attach/1_DofC-2016Conference-Proceedings.pdf 


\section{FIGURE 17. EXAMPLE OF AGRI-FOOD INDUSTRY CLUSTER}

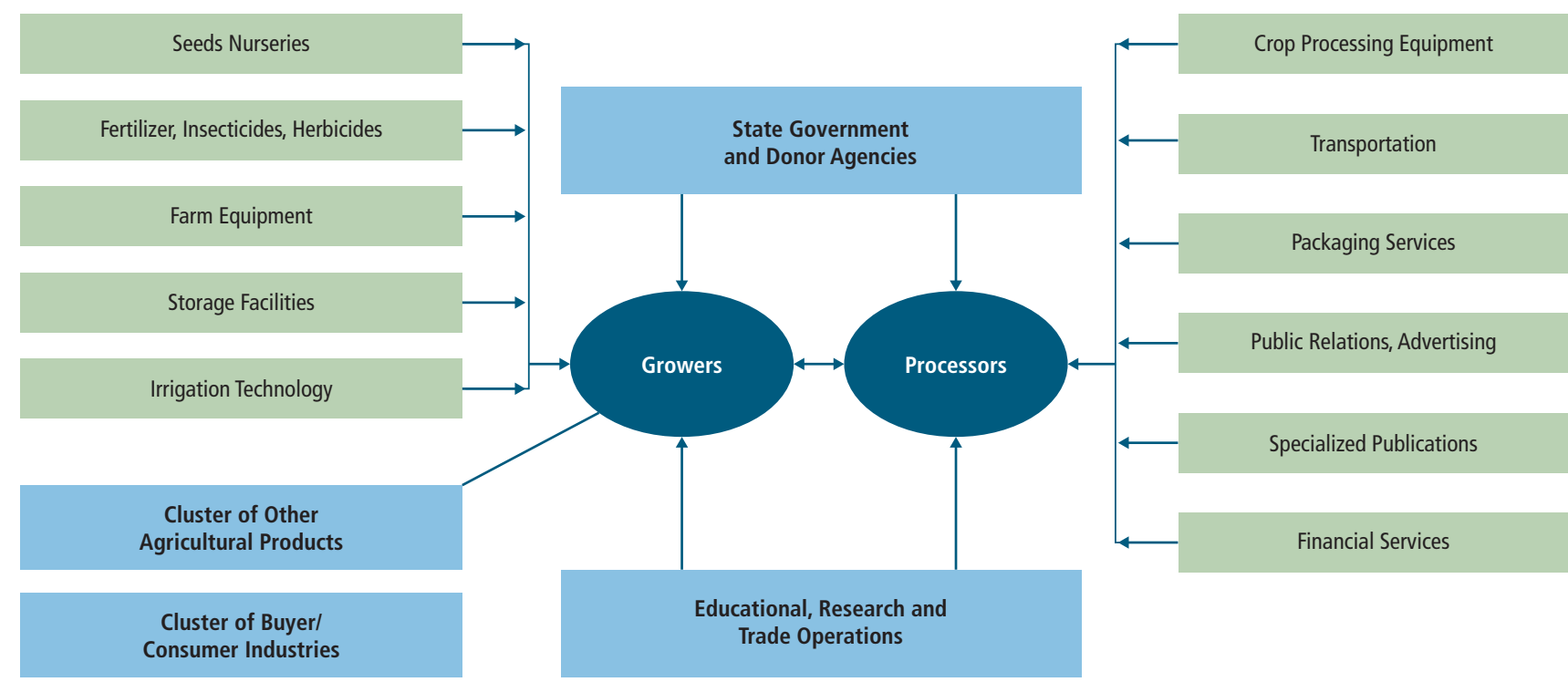

Source:World Bank (2009). Clusters for Competitiveness - A Practical Guide \& Policy Implications for Developing Cluster Initiatives. International Trade Department, PREM, World Bank, Washington D.C.

\section{c) Incentivizing innovation and entrepreneurship}

59. Public funding for research and innovation must be increased on the basis of well-coordinated innovation policies and systems. Under the European Framework Program for Research and Innovation, "Horizon 2020", the EU aims to invest 3 percent of the EU's GDP in R\&D by 2020. Since July 2014, all countries of the Western Balkans, with the exception of Kosovo, have been "associated countries" of Horizon 2020. However, while increasing between 2009 and 2012, the WB countries (except for Serbia) currently invest less than 0.5 percent of their GDP on R\&D compared to the EU average of 2 percent. On average, 10 percent of gross domestic expenditure on research and development in the region stems from international sources (primarily Horizon 2020), which is the same percentage as in the EU countries. In order to enhance the impact of public funds for research and innovation, government expenditures must be underpinned by strong policy governance systems. This includes the development of dedicated innovation strategies, national policy co-ordination bodies (with representatives from relevant ministries, academic institutions and the private sector), independent implementing agencies and funding instruments, and policy monitoring and evaluation systems. Most of the countries in the Western Balkans are preparing general innovation strategies to better manage the increasing number of policy instruments and actors involved in their innovation systems. In this context, they are emphasizing the need for international and regional co-operation. North Macedonia is currently the most advanced in terms of moving forward its innovation agenda. It adopted a dedicated national innovation strategy in 2013, established independent funding agencies and created national policy coordination mechanism in the form of a National Committee for Innovation and Entrepreneurship under the Prime Minister's Office, as well as an Advisory Group for Innovation. Although Serbia and Albania have set up independent agencies to implement innovation programs, other countries still manage implementation through line-Ministries. ${ }^{77}$ As a result, the relationship between national innovation policies and agri-food innovation instruments remains weak in most WB countries.

60. Collaborative research and innovation can further enhance the socio-economic impacts of public funding for research and innovation. Collaboration between governments, research institutions and industry are playing an increasingly important role in developing innovation and transferring technologies that are beneficial to both industry and society. EU countries have developed and implemented several mechanisms to overcome stakeholder coordination challenges in their innovation systems. They include

77 OECD. 2016. Competitiveness in South East Europe: A Policy Outlook, Competitiveness and Private Sector Development, OECD Publishing, Paris, p137. 
innovation vouchers, ${ }^{78}$ business-led collaborative grants programs $^{79}$ (example in Box 7), technology transfer offic$\mathrm{es}^{80}$ joint innovation and technological networks, as well as regional consortia-led projects. In the WB region, few institutions and policy instruments currently support innovation collaboration between the business and academic research communities. Although WB countries have introduced some form of competitive project funding in addition to institutional funding to research institutions, very few have included patents or co-operation with industry as grounds for awarding projects. Montenegro is the only economy in the region to have introduced a dedicated collaborative grant scheme. $^{81}$ In addition, beyond a pilot scheme in Kosovo, innovation vouchers have not been used systematically in the Western Balkans to build linkages between companies and researchers. ${ }^{82}$ Finally, although universities in the WB region have started setting up technology transfer offices, they remain the most underdeveloped form of institutional support for innovation.

61. Targeted technical and investment support for agrifood SMEs and start-ups is required to facilitate market-driven innovation. According to a study conducted by FoodDrinkEurope in 2014, consumer needs and expectations are the main driving forces for innovation in agri-food value chains. ${ }^{83}$ In general, innovation in the agri-food industry goes well beyond traditional R\&D focused on new or improving existing products. It also includes the implementation of new processing or formulation techniques (e.g. new types of conservation, additives and flavors), logistics and food chain management arrangements (e.g. farm-to-fork approach), packaging (e.g. physical packaging, provision of consumer information), marketing methods, and rebranding, as well as organizational and managerial changes. Innovation relevant to the agri-food industry can moreover take place in other segments of the agri-food chain, including suppliers and related industries such as the chemicals and packaging sectors.$^{84}$ As a result, agri-food SMEs require targeted technical and investment support to improve their processing and marketing capacities in line with market needs.

\section{Access to finance remains the most important con-} straint to innovative agri-food SMEs and start-ups. While bank financing is relatively well developed throughout the region and is businesses' primary source of finance, access to bank finance for SMEs and start-ups is generally constrained by high interest rates, limited competition, complex procedures and collateral requirements. ${ }^{85}$ Moreover, funding for research and innovation is particularly difficult to access as it is often too long-term and high-risk for investors. Some WB countries have been providing grants for private sector research and innovation activities. For example, the Innovation Fund of Serbia has been supporting business research and innovation activities since 2012 and includes an agri-food sector window (see Box 8). North Macedonia, for its part, has recently set up its Fund for Innovation and Technology Development. However, there are currently few other policy instruments to stimulate private sector research and innovation activities. While technology incubators $^{86}$ are the most developed form of institutional support for innovative start-ups, these initiatives tend to be largely donor-funded and often struggle to achieve sustainability.

78 Innovation vouchers are small lines of credit that enable SMEs to purchase services from public knowledge providers. They are designed as incentives for small firms to introduce innovations (new products, processes or services) in their business operations. Innovation vouchers are also important as they afford SMEs opportunities for greater exposure to public knowledge providers such as universities and research organizations. They thus help SMEs overcome obstacles like their perceptions of public institutions as irrelevant to business or their reluctance to take on the costs of identifying relevant providers.

79 Cooperative grants programs give businesses opportunities to launch joint research initiatives with researchers. Typically, they require the joint participation of research organizations and businesses and often require some level of co-financing. Such partnerships can be short- or long-term and are often centered on a firm-specific problem.

80 Technology Transfer Offices (TTOs) assist public research organizations in managing their intellectual assets and transforming them into benefits for the wider economy and society at large. TTOs also help facilitate the transfer of knowledge to the private sector either through spin-offs or licensing agreements. They also facilitate contractual research and assist in the protection and management of intellectual property, all of which generate revenues for higher education. TTOs have recently taken on another function-the funding of proof-of-concept type activities through their own seed funds. 81 Under its Higher Education and Research for Innovation and Competitiveness Project (HERIC), R\&D funding is given to consortia where there is at least one domestic and one foreign R\&D institution, and one business partner.

82 OECD. 2016. Competitiveness in South East Europe: A Policy Outlook, Competitiveness and Private Sector Development, OECD Publishing, Paris, p159.

83 FoodDrinkEurope (2014). Data \& Trends of the EU Food Industry 2013-2014

84 Product packaging innovations have become particularly important to food and beverage manufacturers in enabling the success of new products by building stronger connections with consumers and reducing waste. Innovations focused on packaging represented 30 percent of innovations in the modern retail sector in the EU in 2012 compared to just 6 percent in 2004. By contrast, the shares of new product varieties and range extensions decreased from 40 percent in 2004 to 30 percent in 2012.

85 For example, foreign and domestic banks continue to apply interest rates that are higher than the EU average of around 6.3 percent. While rates in Serbia exceed 18 percent, they hover around 9 to 10 percent in the other SEE economies.

86 Examples include the Innovation Centre in Kosovo, the Innovation Centre in Banja Luka and the Business Technology Incubator of Technical Faculties in Belgrade. 


\section{BOX 7. THE UK SUSTAINABLE AGRI-FOOD INNOVATION PLATFORM}

The Technology Strategy Board (now called InnovateUK) is a business executive-led, non-department public body reporting to the Department for Business, Energy and Industrial Strategy dedicated to promote research, technology, and innovation (http://www.innovateuk.org). The Sustainable Agri-food Innovation Platform was launched by the Technology Strategy Board in October 2009 in partnership with the Department for the Environment, Food and Rural Affairs (Defra) and the Biotechnology and Biological Sciences Research Council (BBSRC). Over five years, it invested up to $£ 90$ million in business-led collaborative projects (matching the investment by industry) to develop new technologies in support of global food security and environmental sustainability. Priority areas included crop protection (2009), sustainable protein production (2010), food processing and manufacturing (2011), measurement technologies (2012) and engineering for agri-food (2013). The competitive call in 2014 invested over $€ 11$ million in business projects to improve the resource efficiency and resilience of the food and drink supply chains. The aim was to help companies develop innovative ways to: reduce the production of waste; use resources such as energy, water and raw materials more efficiently; improve the productivity of food manufacturing and processing operations; improve the resilience of the food supply chain by making better use of resources; and reducing environmental stresses on food systems.

Source: https://connect.innovateuk.org/web/sustainable-agriculture-and-food-innovation-platform

\section{BOX 8. SERBIA'S INNOVATION FUND}

The Innovation Fund in Serbia was established by the Law on Innovation Activity in 2011, and is funded by the EU's Instrument for Pre-accession Assistance (IPA) with expert support from the World Bank. The Fund's main goal is to support innovation in science and technology, and commercialize technology transfer in Serbian enterprises. In three years of functioning it has spent $€ 6$ million on 53 projects, and continues working on new projects to support commercialization of research and development (R\&D) through encouraging collaboration among stakeholders. The Innovation Fund provides financial help for R\&D and innovation in commercial enterprises in Serbia. It is among the few sources providing risk financing, as other sources of private funding for businesses in initial stages of development, such as business angels' networks, crowd funding and venture capital, barely exist in the country. It therefore complements existing government support for innovation projects.

The Fund operates through two different programs: mini grants and matching grants. Both programs require applicants to be majority owned Serbian enterprises, and the projects can be targeted at any field of science and technology as well as other sectors. Mini grants are aimed at early-stage micro- and small enterprises that have market-oriented technological innovation with a high potential for commercialization. Projects must be designed to be completed in under a year, and those receiving awards get an unconditional grant amounting to a maximum 85 percent (or $€ 80,000$ ) of the total funds necessary for successful execution. Matching grants target existing micro-, small- and medium-sized enterprises (defined by a revenue ceiling in the last two years) looking to scale up their production and translate research efforts into commercial projects. A project must be designed to be completed in under two years and the Fund is willing to dispense a maximum of 70 percent (up to $€ 300,000$ ) of its cost, with the remainder having to be secured by a co-financer independent from the Fund. Grants in this category are not unconditional. If the project is successful, the applicant will be required to pay royalties or pay back the grant with interest. The risk of not succeeding is shared between the applicant and the Fund and, in cases of unsuccessful commercialization, no payment is required.

In three years of functioning, the Fund went through four public calls for projects, with 471 applications, mostly from hi-tech companies in ICT, energy efficiency and nanotechnology, but also food and agriculture, machine and mechanical engineering and electromechanical device production. It disbursed all planned funds, equally divided between mini grants and matching grants. By 2014 the results had been encouraging. Out of 53 awarded projects, 23 patent applications had been submitted (plus 8 trademark and 6 copyright applications), 13 companies had established new business relationships or partnerships, 11 companies had generated revenue from the sale or lease of products or services, and 7 companies had established strategic international cooperation. Currently, the Innovation Fund is preparing a Serbia Research, Innovation and Technology Transfer Project, supported by €6.9 million from IPA funds, with the goal of promoting technology transfer and commercializing R\&D efforts by stimulating collaboration between academia and industry, in addition to offering collaborative R\&D grant schemes. The Fund is also actively representing the government of Serbia in the dialogue and designing of new financial instruments for private sector development within the framework of the Western Balkans Enterprise Development and Innovation Facility.

Source: Sanfey, P. et al. (2016). How the Western Balkans can catch up, EBRD Working Paper No. 186, London, p43. 
63. Successful innovation among agri-food SMEs and start-ups could be further promoted by building an entrepreneurial culture and strengthening financial literacy. Entrepreneurial learning is not only a priority in the Small Business Act for Europe (2008), but also in the EU's overarching Europe 2020 strategy and its Entrepreneurship 2020 Action Plan. Despite increasing efforts to incorporate entrepreneurial learning in their education and training systems, WB countries still face challenges in promoting a culture of market entrepreneurship. In particular, policy coordination and partnerships between key public and private players must be further developed to align entrepreneurial learning with sector-based education strategies, SME development, employment and R\&D. Furthermore, aspiring entrepreneurs are often ill-informed on financial markets and the financing options that are available to them due to a lack of financial literacy and investment-readiness throughout the region. ${ }^{87}$ Financial literacy training could educate entrepreneurs in the workings of the financial system, help them understand the different types of financing instruments available and how to access them. Programs could also include courses on how to design and present business plans to possible investors. While Serbia and Kosovo have introduced financial literacy and investment-readiness programs, ${ }^{88}$ North Macedonia and Albania are in the early stages of program development. National strategies and policies addressing financial readiness have not yet been put in place in $\mathrm{BiH}$.

\section{d) Building sector-specific human capital}

64. Education and training programs must be closely matched with agri-food industry needs. WB countries have a well-educated workforce at the secondary level, but quality issues and higher-level skills gaps persist. ${ }^{89}$ Countries in the Western Balkans generally lack a coordinated approach to matching education outcomes with labor market needs. Employment in the agri-food industry could thus be strengthened by using skills gap analyses to introduce curriculum-based solutions in the education systems of WB countries. VET systems are another key part of efforts to facilitate school-to-work transition as it gives young people valuable professional experience and the opportunity to acquire practical skills. WB countries have adopted policy documents articulating medium- and long-term visions for their VET systems. They also perform skills gap analyses using the outcomes of business surveys conducted by employment services to inform the design of short-term training schemes. However, current systems are ill-equipped to identify agrifood sector-specific needs. The business community should also take a more active role in VET policy making and particular attention should be given to quality assurance policy and practice in work-based learning. ${ }^{90}$ Sector-based skills councils could be established that use the outcomes of training needs analyses as a basis for a more evolved dialogue about training requirements between government, business and (small) business support service providers (example in Box 9).

\section{e) Promoting foreign direct investment and trade}

65. Foreign direct investment can play an important role in
transferring technology and improving access of agri-food businesses to international markets. While it may be unrealistic to expect WB countries to become innovation leaders in the near term, businesses could move closer to the technological frontier by adopting technologies that have been developed elsewhere with, occasionally, some adjustments to the local market. Foreign direct investments (FDI) can be an effective vehicle for this kind of transfer of technology and know-how to the region. They also enable businesses to participate in the international value chains often associated with foreign investments, which may in turn incentivize further innovation compared to businesses involved in more local activities. Governments could further facilitate FDI by establishing one-stop shops for foreign investors to obtain the permits and support needed to establish their business operations, ease foreign investors' access to land, and establish FDI-SME linkage programs to help foreign investors adapt to local markets and support domestic suppliers. All WB countries have created investment promotion agencies, but they are still in the process of establishing services such

87 OECD. 2016. Competitiveness in South East Europe: A Policy Outlook, Competitiveness and Private Sector Development, OECD Publishing, Paris, p128. 88 Between 2014 and 2020, Serbia is running an investment-readiness program as part of the Integrated Innovation Support Program, funded by the EU's Pre-Accession Fund. Kosovo, for its part, operates a voucher scheme for companies to utilize for training purposes, while the government has developed a program specifically aimed at female and young entrepreneurs.

89 Whereas the share of the labor force with a higher education in the WB countries (with the exception of Montenegro) is about half that of the EU average, the share of workers with a secondary education is relatively larger in WB economies, particularly in BiH. However, PISA data indicates that student performances in mathematics, reading and science in SEE are well below the OECD average in Albania, Montenegro and Serbia. The share of science, technology, engineering and mathematics (STEM) students in tertiary education, which is an important indicator capturing human capital crucial for adopting and creating technologies, is a bit lower on average than in EU countries. The exception is Serbia, which has double the share of students in this category compared with the other WB countries given the importance of Belgrade as a regional university center.

90 OECD. 2016. Competitiveness in South East Europe: A Policy Outlook, Competitiveness and Private Sector Development, OECD Publishing, Paris, p103. 


\section{BOX 9. AUSTRALIA'S AGRI-FOOD INDUSTRY SKILLS COUNCIL}

Industry skills councils in Australia are (i) recognized and funded by the government; (ii) governed by independent and industry-led boards; and (iii) non-profit companies limited by guarantee. Their role is to focus on: (i) providing integrated industry intelligence and advice to government and enterprises on workforce development and skills needs; (ii) actively supporting the development, implementation and continuous improvement of high quality training and workforce development products and services, including training packages; (iii) providing independent skills and training advice to enterprises, including matching identified training needs with appropriate training solutions; (iv) working with enterprises, employment service providers, registered training organizations and government to allocate training places; and (v) engaging with State and Territory Governments, State and Territory industry advisory bodies and peak representative bodies in their area of industry coverage.

The Agri-Food Industry Skills Council was established in May 2004 as the peak body for agri-food industry skills and workforce development in Australia. The council represents the agri-food industry through its 14-member private sector board and five industry standing committees representing the broad industry sectors (food processing, rural and related industries, meat, seafood, racing). The council's strategic intent is to improve the business performance of the agri-food industry through the development and implementation of innovative skill and workforce solutions. It operates in close partnership with these sectors to sustain and simplify high-quality, nationally-recognized training products and services. The council also seeks to ensure that training providers deliver outcomes that serve industry needs. The council reports to the Federal Government for funding and operational performance through the Department of Education, Science and Training.

Source: http://www.ivet.com.au/a/35.html

as one-stop shops and linking foreign investors with SME supplier databases. In addition, the design and promotion of FDI incentive schemes are not fully developed, strategic investor targeting is still an emerging practice and aftercare services are limited. Although foreign investors are generally allowed to purchase or lease farm land, administrative procedures for doing so are often more burdensome for foreign than for domestic investors and some countries may restrict foreign ownership of certain types of land to ensure food self-sufficiency or control inflation. ${ }^{91}$

\section{Export promotion and trade facilitation measures can} further boost agri-food export growth. In addition to promoting compliance with international food safety and quality standards, agri-food exports can be supported through promotional activities and campaigns such as participation in trade fairs, missions and buyers forums. Success of these activities depends above all on a clear stance on the positioning of national product offerings abroad, in combination with an in-depth understanding of consumer preferences and other requirements in the export markets. Given the level of expertise and wide range of services involved, many countries have created specialized agencies (e.g. ApexBrasil, ProChile) to support the private sector on exports. Export promotion services provided by specialized agencies may include the development of single portals that provide members with up-to-date information on standards, regulations and other marketing requirements (Box 10). Services may also include support to accessing trade finance or export insurance. While all WB countries have export promotion policies in place, their level of implementation varies. ${ }^{92}$ Lastly, agri-food exports can be facilitated by streamlining customs and border crossing procedures. While WB countries have made significant progress in reducing time and costs to import and export, important administrative barriers remain, especially with respect to enquiry points, customs documentation, automation and the implementation of riskbased customs procedures and processes. ${ }^{93}$

\section{Digital marketplaces could help food and beverage} manufacturers forge direct links with buyers and consumers. While digitalization has been a growth driver in the distribution of food and beverages, the agri-food industry is generally somewhat lagging behind leveraging e-commerce platforms (Box 11). However, food and beverage manufacturers could use online marketplaces as effective tools to sell on a business-to-business or business-to-consumer basis. First of all, e-commerce platforms enable manufacturers to

91 OECD. 2016. Competitiveness in South East Europe: A Policy Outlook, Competitiveness and Private Sector Development, OECD Publishing, Paris, p43.

92 North Macedonia and Serbia have the most complex programs, offering a wide range of services and export promotion activities. Albania and Montenegro have integrated export promotion programs, but they are more limited and, particularly in Montenegro, financial support for them has declined. BiH and Kosovo have only a limited export base and their export promotion initiatives are conducted on an ad hoc basis.

93 OECD. 2016. Competitiveness in South East Europe: A Policy Outlook, Competitiveness and Private Sector Development, OECD Publishing, Paris, p73. 


\section{BOX 10. AGRI-FOOD PROMOTION PORTAL}

A new online tool has been launched to help European agri-food producer organizations in their efforts to promote their products. The new agri-food promotion portal is managed by the Consumers, Health, Agriculture and Food Executive Agency (CHAFEA) on behalf of the European Commission, and is a designed to be a one-stop-shop for organizations to find out how to get EU funding for their promotion programs, search for potential program partners and find useful information on entering new export markets. Interested visitors will find a wealth of information on a wide range of useful topics, from the rules on developing promotional programs to networking techniques designed to help find potential partners. They will also find all the latest information on events and campaigns organized by the Commission, mainly outside the EU, and learn how to go about joining Commissioners' high-level visits to potential new markets. The new portal is also designed to help SMEs with information about market access and market entry, protection of intellectual property rights, sanitary and phytosanitary measures (on plant and animal health), market research and other vital information for anyone looking to push their products into new export markets. Designed to be an interactive tool, the portal offers tailor-made webinars to help organizations design their promotion activities and share examples of current campaigns to help inspire them. It also allows registered organizations to find potential partners through an online 'speed dating' tool.

Source: CHAFEA, Promotion of Agricultural Products. Available at: http://ec.europa.eu/chafea/agri/

\section{BOX 11. E-COMMERCE - A PROMISE UNFILLED FOR THE AGRI-FOOD INDUSTRY?}

The internet creates immediate opportunities for food and beverage manufacturers to reach both B2C and B2B. Datassential, a Chicago-based food research firm, recently examined the food e-commerce market and identified three different markets: (i) prepared meal delivery; (ii) meal kit delivery; and (iii) grocery/packaged goods delivery. E-commerce has expanded rapidly as retailers and other marketers of consumer packaged goods offer consumers the ability to shop online, letting them shop when and where they want. The agri-food industry, however, has been the slowest major consumer sector to expand into e-commerce growth, due to issues such as freshness, product damage, low margins compared to other consumer products and logistical challenges. However, a review of food and beverage e-commerce initiatives suggests that the agri-food industry's e-commerce challenge is a marketing one more than a logistics one: while logistics play an important role in the economics of e-commerce, the e-tailers that best understand consumer needs are likely to win the future. Since the advent of e-commerce, B2C e-commerce players have expanded into B2B, and vice versa. However, because differences exist in the economics of warehousing, inventory management, order fulfillment and delivery functions for B2C and B2B, food and beverage manufacturers must decide which of these audiences to pursue.

Source: http://www.foodlogistics.com/article/12021908/food-and-beverages-push-into-e-commerce-raising-questions-for-the-supply-chain

reach and communicate with businesses and consumers directly, build brand loyalty and gain feedback about existing and new products faster and more cost effectively. ${ }^{94}$ Digital marketplaces also create new opportunities for the market entrance of smaller, single-focus food and beverage manufacturers. Finally, they offer the possibility of production-on-demand, which may help the agri-food industry to micro-manufacture in line with buyer and consumer demands.

\section{f) Diversifying the rural economy}

\section{Successful agri-food sector transformation depends on} the creation of employment opportunities upstream of agrifood value chains and beyond. As national economies and agri-food sectors modernize, less people will work in primary agriculture and more will work in upstream segments of the value chain. In the EU-15, for example, less than 40 percent of the workforce employed in the agri-food sector is involved in primary production, whereas more than 60 percent is involved in value adding manufacturing and service activities (Figure 18). There thus remains significant scope in all WB countries for further transforming their agri-food sectors into purveyors of decent jobs upstream of core agri-food value chains. However, even if such transformation creates new and more rewarding agri-food system jobs, the sector alone is unlikely to absorb all the current surplus labor in rural areas. Complementary development initiatives focused on creating diversified and knowledge-based rural economies that provide decent jobs beyond core agri-food value chains are needed to ensure success.

94 https://ec.europa.eu/research/innovation-union/pdf/Six_perspectives_on_Retail_Innovation_EG_on\%20Retail_Sector_Innovation_web.pdf 
FIGURE 18. SHARE OF AGRI-FOOD SECTOR EMPLOYEES BY AGRI-FOOD SUB-SYSTEM, 2012

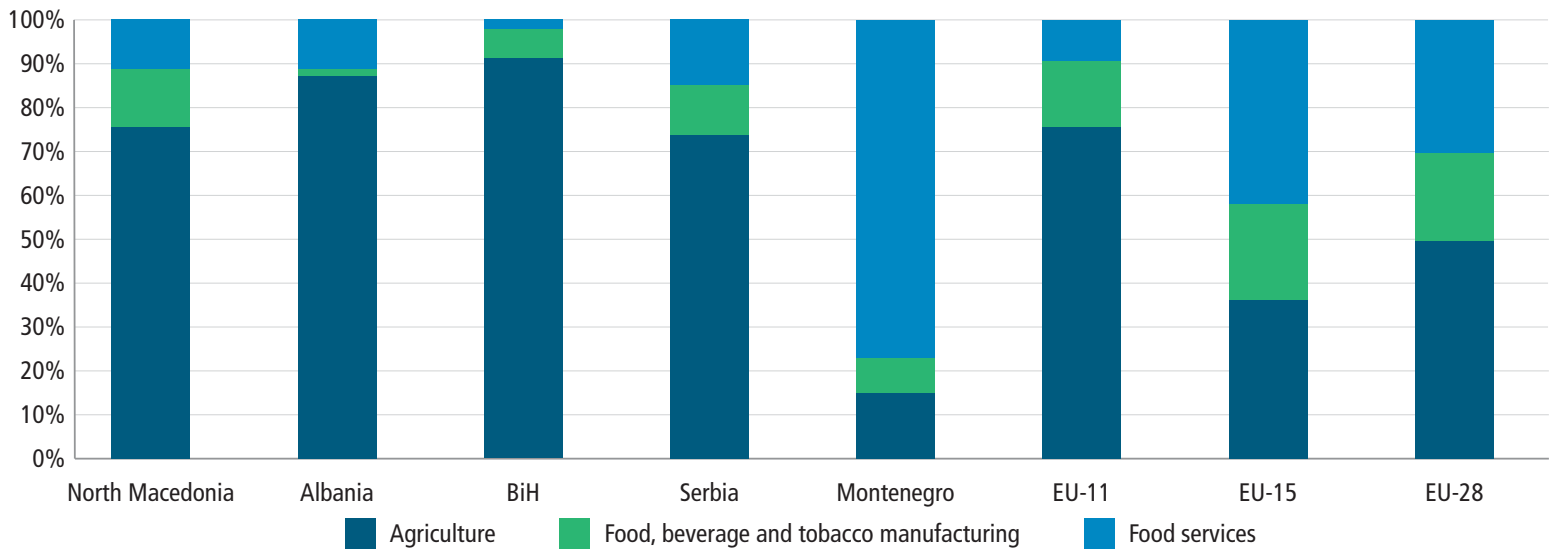

Source: : ILOSTAT, FAOSTAT, UNIDO.

69. Leveraging the agri-food sector's multiple functions and cross-sector linkages can be a powerful driver for diversified and knowledge-based rural economies. The potential of the agri-food sector to unlock broad-based growth and decent jobs in rural areas is significant. Food is not only an industry, but also a social, cultural and health commodity, which has the power to connect people of various ages, cultures, religions and social backgrounds with local cultures and landscapes. The agri-food sector is also one of the most cross-cutting sectors that links with, among others, the areas of biotechnology, information and communication technologies (ICT), research and education, transport and logistics, tourism, health and wellbeing, natural resource management, sustainability innovation, and cultural and creative industries. The linkages between the agri-food and tourism sectors are particularly relevant in the context of the Western Balkans given that the tourism sector contributes significantly to the regional economies. ${ }^{95}$ In general, the OECD revealed that food can play an important role in the development of tourism services given that it often comprises 30 percent or more of tourist expenditure and this money is regularly spent directly with local businesses. As a result, tourism's economic impact can be important not only for businesses that directly provide food for tourists (such as hotels, restaurants and attractions), but also throughout the agri-food value chain, especially if the food provided is supplied locally. Furthermore, a recent report released by the World Tourism Organization stresses the importance of food as an immaterial cultural heritage, which can enhance the reputation of destinations worldwide and differentiate locations. Specialty foods are thus becoming an essential component in destination choice motivation and gradually replacing geographical location as part of the destination marketing mix. ${ }^{96}$ By linking food tourism, which is perceived as a high-yield market, to other products such as cultural and natural heritage sites, the Western Balkans could provide a comprehensive tourism offer.

70. Participatory development approaches that are supported by different levels of Public Private Partnerships are key to integrating modern agri-food value chains in the broader rural economy. Given the wide-ranging characteristics of rural areas, there is no "one-size fits all" approach to integrating modern agri-food value chains inside diversified and knowledge-based rural economies. In fact, a mix of approaches and tools currently exists to support place-based, cross-sectoral development strategies. At the local level, the so-called LEADER approach has been a key component of the EU's rural development policy for more than 20 years. It constitutes a bottom-up method for involving local public, private and civil society partners in rural communities in shaping local development through so-called "Local Action Groups" (LAG). A new term, "Community-Led Local Development" (CLLD), is now used for a wider application of the LEADER approach. ${ }^{97}$ At the regional level, "smart specialization" is a new policy approach to regional devel-

95 In 2013, receipts from international tourists amounted to 21 percent of GDP in Montenegro and 13 percent of GDP in Albania.

96 Cavicchi, A. and K. Ciampi Stancova (2016). Food and gastronomy as elements of regional innovation strategies, European Commission, Joint Research Centre, Institute for Prospective Technological Studies, Spain.

97 Since 2014, it is possible for a single Local Development Strategy (LDS) to be supported by several EU funds (known as multi-funded CLLD) in order to: (i) enable LAGs to comprehensively integrate local needs and solutions; (ii) enable Leader-type support to be better coordinated with local development support from other EU funds; and (iii) reinforce the links between rural, urban and fisheries areas. 
opment and regional innovation planning. This approach is grounded in a so-called Entrepreneurial Discovery Process (EDP), which builds on region-specific assets, strengths, potentials, capacities, critical mass and expertise. A specific characteristic of the approach is its focus on the diversification of regional economies alongside specialization. The central idea is that a limited number of areas of activities is selected through the EDP to stimulate regional growth, job creation, and collaboration among research and knowledge institutions, businesses and investors. Regional entrepreneurs who are active in research, development and business, drive the identification of new business opportunities, tap- ping into their core competences and combining them with other skills and knowledge inputs with a view to create new combinations that foster unique areas of activities. ${ }^{98}$ Agrifood related priorities are one of the most prominent priority areas selected by EU countries and regions as part of their smart specialization strategies, along with Key Enabling Technologies (KETs), health, energy and the digital agenda (example in Box 12). ${ }^{99}$ The sub-areas most frequently selected included agri-food new technologies (23 percent) followed by agri-food and tourism (20 percent) and food with higher added value (13 percent). ${ }^{100}$

\section{BOX 12. THE FOOD SMART SPECIALIZATION STRATEGY OF LAZIO, ITALY}

A strong relationship between food and local territory is an expression of tradition and culture in the Italian region of Lazio. Food is functional and complementary to tourism, cultural activities and health, which are essential economic activities in the region. The potential for cross-fertilization with Key Enabling Technologies (ICT, nanotech, new materials, biotechnology, etc.), life science, environment and the green economy has been identified as crucial for innovation and technology advancement. Agri-food has been identified as a smart specialization priority through an entrepreneurial discovery process carried out in focus groups involving representatives of the business community, business associations, research institutions and local universities. The entrepreneurial discovery process was complemented with the results of the regional eco-system analysis and fieldwork outcomes: Lazio Deli98 and The Call 4 Innovators@EXPO 2015.

In the region of Lazio, there are approximately 3,400 agri-food enterprises that employ approximately 16,626 workers. The largest number (2,656 agricultural companies out of which 329 with direct sales) is concentrated in the capital city of the region Rome. This makes the city one of the largest agricultural municipalities in Europe. The agri-food sector in Lazio represents 5 percent of the national turnover per year and 3 percent of the total wealth of the entire regional economy. Export of food products accounts for $€ 580$ million (3.3 percent of total manufacturing export). The R\&I system is also well supported by a large number of academic and research institutes including the CRA (Council for Research and Experimentation in Agriculture), AINRAN (National Research Institute for Food and Nutrition)-now CRA-NUT-, INEA (National Institute of Agricultural Economics), ARSIAL (Regional Agency for Development and Innovation of Agriculture of Lazio), ENEA (Italian National Agency for New Technologies, Energy and Development sustainable economic), CNR (National Research Council), IZSLT (Instituto Sperimentale Zooprofilattico Lazio and Tuscany) and Agri BIC Lazio (an incubator of food and agriculture). Additionally, large logistical platforms that make the region significantly important for the commercialization of agri-food products are crucial players in regional agri-food ecosystem and global value chains. The largest regional platforms are the Agribusiness Centre of Rome (CAR), the Fruit and Vegetable Market in Fondi (MOF) and the Fruit and Vegetable Market of Latina (MOL). In terms of international collaboration, Lazio seeks to promote and position better quality products that are characteristic of the local culture and linked to local gastronomy in international markets. At the same time, the region seeks to intensify the exchange of know-how and technology transfer in the fields related to food processing including precision farming, plant production in challenging environments, packaging and preservation, certification and inspection, etc.

Source: Cavicchi, A. and K., Ciampi Stancova (2016). Food and gastronomy as elements of regional innovation strategies, European Commission, Joint Research Centre, Institute for Prospective Technological Studies, Spain, pp. 30-31.

98 Cavicchi, A. and K. Ciampi Stancova (2016). Food and gastronomy as elements of regional innovation strategies, European Commission, Joint Research Centre, Institute for Prospective Technological Studies, Spain.

99 Eye@RIS3 database is an open access database managed by the S3 Platform. The database contains information on S3 priorities selected by EU countries and regions. As of December 1st, 2015, 25 countries and 178 regions encoded their priorities. The database is available at the S3 Platform webpage: http://s3platform.jrc.ec.europa.eu/map

100 The most frequent key words used by EU countries and regions to describe "agri-food new technologies" specialization are biotechnology, (food) technology, KETs and ICT. The most frequent key words used to describe "agri-food and tourism" are (sustainable) tourism, eco-tourism, experience-based industry, and health and wellness tourism. The most frequent key words used to describe "food with higher added value" are health, healthy (organic) food, nutrition and life sciences. 
and survey (Albania) data was utilized to disaggregate the agri-food sector, while in the case of North Macedonia, supply and use tables were processed to construct an IO table.

To estimate economic impacts associated with agri-food activity, different types of scenario, were specified and their impacts on economy-wide output, value added and employment, estimated. The first type was associated with changes in agricultural and rural development policy, while the second type dealt with changes in economic structures, and namely, an increase in the (currently low) economic linkages between agriculture and food processing and increases in agri-food output. Finally, another Scenario was run and involved the assumption that the agri-food sector ceased to exist in both countries.

Policy scenarios specified reflect either different mixes of agricultural and rural development policies, while structural scenarios reflect policy needs identified by other assignments of the project and various background reports dealing with agri-food sector in the region. Finally, the "no agri-food" scenario was run in order to assess the full economic impacts of the sector in the two economies.

Eight common policy scenarios were specified and compared to the 2011-2015 baseline; these are as follows:

Baseline Scenario 0 - Status Quo/No Change in Policy: Agricultural and rural development policy measures and expenditure fixed at 20112015 levels.

Scenario 1 - Pillar 1 Support: Policy support is specific only to Pillar 1 (Market and direct producer support).

Scenario 2 - $\quad$ Pillar 2 Support: Policy support is specific only to Pillar 2 (Rural development).

Scenario 3 - $\quad$ Farm Modernization Pillar 2: Agricultural and rural development policy measures and expenditure fixed at 2011-2015 levels, but rural development policy supports only farm modernization.

Scenario 4 - $\quad$ Food Processing Pillar 2: Agricultural and rural development policy measures and expenditure fixed at 2011-2015 levels, but rural development policy supports only food processing.

Scenario 5 - $\quad$ Rural Infrastructure Pillar 2: Agricultural and rural development policy measures and expenditure fixed at 2011-2015 lev- els, but rural development supports only investment in rural infrastructure.

Scenario 6- Rural Income Diversification Pillar 2: Agricultural and rural development policy measures and expenditure fixed at 2011-2015 levels, but rural development supports only investment in rural diversification.

Scenario 7 - Re-orientation of Support: Agricultural support (Pillar 1) is fixed at 2011-2015 levels, but rural development support observes IPARD 2014-2020.

Scenario 8 - Rebalancing Scenario: Agricultural support (Pillar 1) decreases by 20 percent and the equivalent amount is added to IPARD 2014-2020 funds.

Further, a number of country-specific structural scenarios were also specified.

In the case of Albania, these are as follows:

Scenario AL1 - No Agri-food: The agri-food sector ceases to exist.

Scenario AL2 - Double Livestock Production: Meat and milk production doubles, compared to 2013 levels.

Scenario AL3 - Double Fruit and Vegetables Production: Fruit and vegetables output doubles, compared to 2013 levels.

Scenario AL4 - Double Links of Livestock Production: The agri-food sector doubles its purchases of domestically-produced livestock, compared to 2013 levels.

Scenario AL5 - Double Links of Fruit and Vegetables Production: The agri-food sector doubles its purchases of domestically-produced fruit and vegetables, compared to 2013 levels.

Scenario AL6 - Double Links in the Agri-food Chain: The agri-food sector doubles its purchases of domestically-produced agricultural products, compared to 2013 levels.

In North Macedonia, the structural scenarios are as follows:

Scenario MK1 - No Agri-food: The agri-food sector ceases to exist. 
Scenario MK2 - Double Livestock Production: Meat and milk production doubles, compared to 2013 levels.

Scenario MK3 - Double Fruit and Vegetables Production: Fruit and vegetables output doubles, compared to 2013 levels.

Scenario MK4 - Double Forage Production: Forage output doubles, compared to 2013 levels.

Scenario MK5 - Increased Links in the Agri-food Chain: The agri-food sector doubles its purchases of domestically-produced agricultural products, compared to 2013 levels.

\section{Scenario Results}

Tables 9 and 10 summarize and attempt to interpret the policy scenario impacts for both countries in comparison to the impacts generated by the status quo/no change in policy scenario, while Tables 11 and 12 present percentage changes (compared to 2013 levels) in output, value added and employment of the structural scenario impacts.

TABLE 9. IMPACTS OF POLICY SCENARIO COMPARED TO STATUS QUO (RATIO: SCENARIO IMPACTS/STATUS QUO IMPACTS), ALBANIA

\begin{tabular}{|c|c|c|c|}
\hline Impacts compared to no change in policy & Change in output & Change in value Added & Change in employment \\
\hline \multicolumn{4}{|l|}{ ALBANIA } \\
\hline Pillar 1 Support & $-12 \%$ & $-8 \%$ & $6 \%$ \\
\hline
\end{tabular}

If all policy funds go to Pillar 1, economy-wide output and value added decrease (due to agriculture's low links with the rest of the economy), but employment increases by $6 \%$, as agriculture is characterized by a comparatively high labor intensity.

Pillar 2 Support

$14 \%$
$14 \%$

$13 \%$

If all policy funds go to rural development, economy-wide output, value added and employment increase by $13-14 \%$, as sectors which benefit have comparatively higher (compared to agriculture) economic links with the rest of the economy.

Pillar 2: Farm modernization

$-1 \%$

$7 \%$

$10 \%$

If Pillar 2 funds are used for farm modernization, employment increases by $10 \%$ mainly due to the fact that the trade sector (which provides a large share of investment goods) is labor intensive.

Pillar 2: Food processing

$0 \%$

$6 \%$

$10 \%$

If Pillar 2 funds are used for food processing modernization, employment increases by $10 \%$ mainly due to the fact that the trade sector (which provides a large share of investment goods) is labor intensive.

Pillar 2: Rural infrastructure

$0 \%$

$-4 \%$

$-6 \%$

If Pillar 2 funds are used for rural infrastructure, employment decreases mainly due to the fact that the construction sector (which provides a large share of investment goods) generates a comparatively lower (to other sectors) number of jobs per output unit.

Pillar 2: Rural income diversification
$0 \%$

$-1 \%$

$-2 \%$

If Pillar 2 funds are used for rural diversification, employment decreases mainly due to the fact that the construction sector (which provides a large share of investment goods) generates a comparatively lower (to other sectors) number of jobs per output unit.

Re-orientation of support/rebalancing
$14 \%$

$17 \%$

$18 \%$

The implementation of IPARD is projected to generate a significant increase in output, value added and employment due to the increase of policy funds. 


\section{TABLE 10. IMPACTS OF POLICY SCENARIO COMPARED TO STATUS QUO (RATIO: SCENARIO IMPACTS/STATUS QUO}

IMPACTS), NORTH MACEDONIA

\begin{tabular}{|c|c|c|c|}
\hline Impacts compared to no change in policy & Change in output & Change in value added & Change in employment \\
\hline NORTH MACEDONIA & & & \\
\hline Pillar 1 Support & $0 \%$ & $2 \%$ & $1 \%$ \\
\hline
\end{tabular}

If all policy funds go to Pillar 1, economy-wide impacts increase marginally, as agriculture is characterized by comparatively high links with the rest of the economy.

Pillar 2 Support

$-1 \%$

$-7 \%$

$-3 \%$

If all policy funds go to rural development, economy-wide output, value added and employment decrease, as sectors which benefit have comparatively lower (compared to agriculture) economic links with the rest of the economy.

Pillar 2: Farm modernization

$0 \%$

$0 \%$

$1 \%$

A focus of rural development funds on farm modernization creates marginally positive employment impacts, mainly due to the fact that the trade sector (which provides a large share of investment goods) is labor intensive.

Pillar 2: Food processing

$2 \%$

$3 \%$

$4 \%$

If Pillar 2 funds are used for food processing modernization, economic impacts are positive mainly due to the fact that the trade sector (which provides a large share of investment goods) has comparatively high links with the rest of the economy.

Pillar 2: Rural infrastructure $-1 \%$

$-2 \%$

$-2 \%$

If Pillar 2 funds are used for rural infrastructure, impacts are marginally negative, due to the fact that the construction sector (which provides a large share of investment goods) is characterized by its low economic links with the rest of the economy.

Pillar 2: Rural income diversification

$0 \%$

$-1 \%$

$0 \%$

If Pillar 2 funds are used for rural diversification, impacts are marginally negative, due to the fact that the construction sector (which provides a large share of investment goods) is characterized by its low economic links with the rest of the economy.

Re-orientation of support/rebalancing

$-2 \%$

$-1 \%$

$0 \%$

The implementation of IPARD is projected to generate a marginal decrease in output, value added and employment mainly due to the decrease of policy funds. 


\section{TABLE 11. IMPACTS OF STRUCTURAL SCENARIOS}

Changes compared to 2013 (\%)

Change in output

Change in value added

Change in employment

\section{ALBANIA}

No agri-food sector

$-19.73 \%$

$-23.91 \%$

$-47.22 \%$

Economic impacts of the agri-food sector are extremely significant, as this sector accounts (mainly directly) for a very significant share of economic activity. It is noted that indirect links of agri-food with the rest of the economy are rather low, reflecting the relevant economic development context.

Double livestock production

$6.01 \%$

$5.70 \%$

$15.31 \%$

If livestock production doubles, economic impacts are significant and much higher than those associated with changes in policy expenditure and mix.

Double fruits \& vegetables production

$$
2.49 \%
$$

$4.10 \%$

$11.63 \%$

If fruit and vegetables production doubles, economic impacts are significant and much higher than those associated with changes in policy expenditure and mix.

\section{NORTH MACEDONIA}

No agri-food sector

$$
-19.06 \%
$$

$-18.15 \%$

$-30.14 \%$

Economic impacts of the agri-food sector are very significant, as this sector accounts (mainly directly) for a significant share of economic activity. It is noted that indirect links of agri-food with the rest of the economy are higher than those in Albania. This reflects the higher development level of North Macedonia and the existing higher economic interdependence amongst economic sectors.

Double livestock production

Double fruits \& vegetables production

$$
2.40 \%
$$

$6.25 \%$

If livestock production doubles, economic impacts are significant and higher (especially for employment) than those associated with changes in policy expenditure and mix.
$1.15 \%$
$1.73 \%$
$3.12 \%$

If fruit and vegetables production doubles, economic impacts are notable and, in the case of employment, higher than those associated with changes in policy expenditure and mix.
$0.87 \%$ $1.94 \%$

If forage production doubles, economic impacts are notable. 


\section{TABLE 12. IMPACTS OF STRUCTURAL SCENARIOS}

Impacts compared to no change in policy (2013)

\section{Change in output}

Change in employment

ALBANIA

Double livestock links

$2 \%$

$2 \%$

$5 \%$

If the agri-food sector doubles its purchases of domestically-produced livestock, employment in the economy increases by $5 \%$. Also there is a $2 \%$ increase of output and value added. These increases are much higher than those associated with changes in policy expenditure and mix.

Double fruits \& vegetables links

$$
2 \%
$$$$
2 \%
$$

If the agri-food sector doubles its purchases of domestically-produced fruits and vegetables, employment in the economy increases by $6 \%$. Also there is a $2 \%$ increase of output and value added. These increases are much higher than those associated with changes in policy expenditure and mix.

Double food chain links

$3 \%$

$3 \%$

$9 \%$

If the agri-food sector doubles its purchases of domestically-produced farm products, employment in the economy increases by $9 \%$. Also there is a 3\% increase of output and value added. These increases are much higher than those associated with changes in policy expenditure and mix.

\section{NORTH MACEDONIA}

Double food chain links
$16 \%$

$16 \%$

$21 \%$

If the agri-food sector doubles its purchases of domestically-produced farm products, employment in the economy increases by $21 \%$. Also there is a $16 \%$ increase of output and value added. These increases are much higher than those associated with changes in policy expenditure and mix and are attributed to the fact that already-existing high links double and hence, impacts are very significant. 


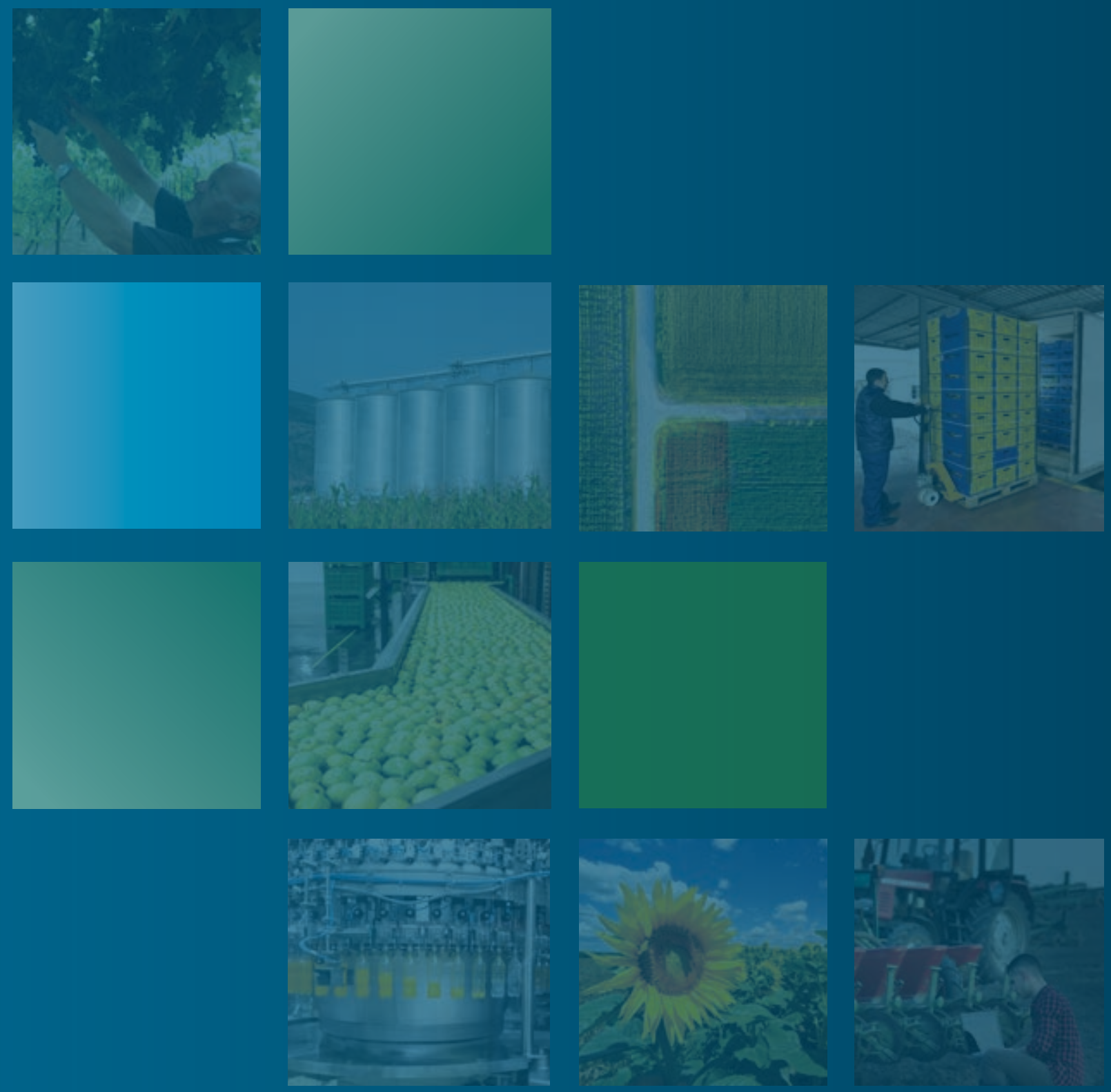

(4) WORLD BANK GROUP

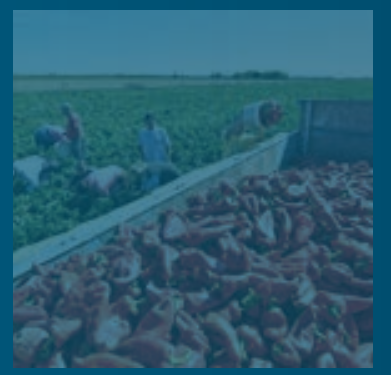

